\title{
CRITICAL RACE REALISM: RE-CLAIMING THE ANTIDISCRIMINATION PRINCIPLE THROUGH THE DOCTRINE OF GOOD FAITH IN CONTRACT LAW
}

\author{
Emily M.S. Houh ${ }^{*}$
}

\section{INTRODUCTION}

This Article comprises the last leg of a larger project I have undertaken on the implied obligation of good faith in contract law. I have argued elsewhere that, as a descriptive matter, the doctrine of good faith and fair dealing in contract law, despite some theoretical controversy in the established scholarship on the doctrine, functions in contemporary contract law not as an implied contract term - as it was originally conceived - but as a rhetorical proxy for judicial analyses of material breach and constructive conditions relating to underlying breach of contract claims. ${ }^{1}$ While such applications of good faith have been of great functional value to courts, lawyers, and students of contract law, I have argued that these developments have caused good faith jurisprudence to languish in an impoverished state and to further detach from the doctrine's equitable roots in implicit contractual obligation. As such, I also have argued from a critical race perspective that, as a normative matter and due to the inadequacies of civil rights remedies, good faith should be used to prohibit discriminatory conduct based on race, gender, sexual identity, age, and/or other categories of identity in the contractual context. ${ }^{2}$

\footnotetext{
* Associate Professor of Law, University of Cincinnati College of Law. J.D., University of Michigan Law School. I am thankful to the Harold C. Schott Foundation at the University of Cincinnati College of Law, whose generous support made the writing of this article possible. I also am grateful to the following people for reading drafts of this article (in its many stages) and for their enormously helpful insights and comments: Pat Chew, Teri Dobbins, Adam Feibelman, Mitu Gulati, Sandra Johnson, Hiroshi Motomura, Camille Nelson, Angela Onwuachi-Willig, Gowri Ramachandran, Duncan Webb, Verna Williams, Ingrid Brunk Wuerth, and Alfred Yen. Finally, I am especially indebted to Joel Frederic, Kevin Hoskins, Jeanette McClellan, and Michelle Pan for their excellent research and editing assistance. All errors made in this article are, of course, mine alone.

1. Emily M.S. Houh, The Doctrine of Good Faith in Contract Law: A (Nearly) Empty Vessel?, 2005 UtAh L. ReV. ___ (forthcoming 2005).

2. Emily M.S. Houh, Critical Interventions: Toward an Expansive Equality Approach to the Doctrine of Good Faith in Contract Law, 88 ConNell L. Rev. 1025 (2003) [hereinafter Critical Interventions].
} 
While the above-referenced discussions of good faith offer descriptive, normative, and theoretical critiques, this Article aims to drive theory and critique into praxis by proposing a common law antidiscrimination claim that, first, incorporates contemporary re-conceptualizations of antidiscrimination jurisprudence, and, second, grounds itself doctrinally not in civil rights law but in the contractually implied obligation of good faith. Moreover, it seeks, through its proposal of the common law claim, to explicitly re-conceive the private law doctrine of good faith as one that might assist in effecting a public law norm of equality.

This Article is divided into five parts. Part I develops from critical race and feminist perspectives how this project envisions equality, as well as how it understands and views discrimination. More specifically, Part I.A. discusses an equality principle that is informed primarily by Professor Iris Marion Young's analytical framework of (in)justice and difference. Part I.B. explores pathbreaking re-conceptualizations of the antidiscrimination principle with an emphasis on Professors Devon Carbado and Mitu Gulati's theory of "working identity," which this Article attempts to operationalize in proposing its good faith discrimination claim.

In a different theoretical vein, Part II explores another branch of jurisprudence that is closely related to critical legal theory of any brand: legal realism. For if this Article seeks to incorporate the public law norm of equality into the private law of contract, it must answer the following question, first raised by the legal realists in the early twentieth century: why does the distinction between private and public law persist and to the extent that it does, should it be blurred in some circumstances? Although these questions were the subject of lively debate throughout most of the twentieth century, the rich and excellent scholarship addressing the public-private distinction had petered out by the mid-1980's, ${ }^{3}$ perhaps because, by then, critical and neoconservative scholars had staked out their intellectual territories so oppositionally and deeply. ${ }^{4}$ Notwithstanding the arrested

3. See Clare Dalton, An Essayin the Deconstruction of Contract Doctrine, 94 YALE L.J.997, 1014 (1985) (arguing that "the Realist challenge to the 'privateness' of contract ha[d] been assimilated and defused" within decades of original challenges in the early 20th century to the public-private distinction).

4. For example, law and economics scholars and critical race theorists have long been at odds with one another, sometimes dismissing each other, quite publicly, out of hand. See, e.g., Richard A. Posner, The Skin Trade, The New Republic, Oct. 13, 1997, at 40 (book review) ("Every intellectual movement has a lunatic fringe. Radical legal egalitarianism is distinguished by having a rational fringe and a lunatic core. The latter is constituted by the critical race theorists and the other legal academics who have swallowed postmodernism hook, line, and sinker. ...”); Richard Delgado, Rodrigo's Second Chronicle: The Economics and Politics of Race, 91 Мich. L. Rev. 1183, 1187-88 (1993) (book review) (describing 
development of private-public theorizing, this Article responds affirmatively to the question of whether the public-private distinction should be blurred in some circumstances. Part II develops what this Article calls "critical race realism" - in part to counter the "racial realism" movement" - to argue that the public-private dichotomy should be explicitly subverted as part of the critical race project when its subversion might facilitate the elimination of both material and ideological racial inequalities that are perpetuated by currently existing legal frameworks. Thus, critical race realism encompasses not only the goals and methodologies of the broader critical race and feminist projects, but also some of the shared goals and methodologies of legal realism and law and market economy theory (which I have integrated into my critical race work elsewhere ${ }^{6}$ ).

Part III of this Article describes how critical race realism might be put to work. Part III.A. sets forth the elements of the good faith discrimination claim, which incorporates critical race realism and is doctrinally grounded in the contractual obligation of good faith. Part III.A. also briefly discusses the appropriate remedy for a breach of the good faith discrimination claim and explains what this claim offers remedially that civil rights claims do not. Part III.B. looks at several cases where plaintiffs asserted, among their various claims, violations of section 1981 of the Civil Rights Act, in order to demonstrate the inadequacy of statutory civil rights remedies to address the different types of subordination and inequality discussed in Part I of this Article. Part III.B. further applies the elements of the proposed common law claim to the facts of these cases, enabling one to see what the good faith discrimination claim offers that existing civil rights claims do not. Part IV of this Article concludes the above discussion.

the difference between legal economists and critical race scholars, Delgado writes: "The law-andeconomics folks .... talk about things like transaction costs, speak of racism as a 'taste,' and spend more time showing why governmental efforts to cure it would be 'inefficient' than they do deploring the practice itself. We, on the other hand, treat racism as subordination, not a mistake, much less an idiosyncratic 'taste,' and struggle to understand its connection with culture, history, and the search for psychic and economic advantage.").

5. See infra Part III.B.

6. See Critical Interventions, supra note 2 (arguing that by screening good faith doctrine through the lenses of critical race and law and market economy theories, using good faith to prohibit improper considerations of race in contracting is consistent not only with equitable principles embodied by doctrines of implicit obligation, but also with contractual goals of protecting parties' bargains, wealth formation, and the facilitation of exchange transactions). 


\section{Defining Equality and Re-Theorizing Discrimination}

\section{A. Equality}

Because this Article is aligned explicitly with the projects of critical race theory and feminist legal theory, it is important to define its use of the term "equality." This article conceives of equality broadly, or "expansively," as I have written elsewhere. ${ }^{7}$ That is, this project's conception of equality encompasses not only formal ${ }^{8}$ and substantive ${ }^{9}$ theories of equality, but also an antisubordination theory of equality that gives primacy to the ways in which power circulates, sociopolitically and socioculturally, to reproduce and sustain white supremacy and male domination. ${ }^{10}$

7. See Critical Interventions, supra note 2, at Part III.A.2. (describing expansive and restrictive views of goals of antidiscrimination law).

8. See Catharine A. MacKinnon, Sex Equality 3-24 (2001). Of formal equality, "the core of conventional equality law," MacKinnon states:

[Formal equality's] familiar calculus — sameness and difference, identity and distinction - requires same treatment if one is the same, different treatment if one is different. The concept is clearly premised on some original just status quo allocation and presupposes a uniform measuring device for whatever is to be distributed. . . . As equality is like treatment for likes, inequality means different treatment for likes, same treatment for unlikes.

Id. at 6 .

9. See Katharine T. Bartlett et al., Gender and Law: Theory, Doctrine, Commentary 265 (3d ed. 2002) ("While formal sex equality judges the form of a rule, requiring that it treat women and men on the same terms without special barriers or favors on account of their sex, substantive equality looks to a rule's results or effects. ... Advocates of substantive equality demand that rules take account of these differences to avoid differential impacts that are considered unfair."). In feminist parlance, substantive equality is sometimes referred to as "difference feminism." The concept of substantive equality made its way into American constitutional law through the famous footnote 4 of the Supreme Court case United States v. Carolene Products Co., 304 U.S. 144, 152 n.4 (1938), which states that "prejudice against discrete and insular minorities may be a special condition, which tends seriously to curtail the operation of those political processes ordinarily to be relied upon to protect minorities, and which may call for a correspondingly more searching judicial inquiry." Id. (emphasis added). Thus, "discrete and insular minorities" constituted the original suspect class, for equal protection purposes, and classifications based on race - specifically the Black race-were thus subject to strict judicial scrutiny due to the histories and legacies of oppression against Blacks in America. In modern constitutional jurisprudence, little to no attention is paid to the "discrete and insular" status of particular minorities; rather, all racial classifications are now subject to strict scrutiny. See Grutter v. Bollinger, 539 U.S. 306, 326 (2003) ("[A]ll racial classifications imposed by government 'must be analyzed by a reviewing court under strict scrutiny."') (citing Adarand Constructors, Inc. v. Pena, 515 U.S. 200, 227 (1995)).

10. See Bartlett et Al., supra note 9, at 533 (stating that antisubordination theory, "sometimes referred to as dominance theory, makes the relevant inquiry not whether women are like, or unlike, men, but whether a rule or practice serves to subordinate women to men. Accordingly, similarities and differences between women and men are important not as givens that that produce certain expected, rational 
This Article's conception of equality is best analogized to Iris Marion Young's conception of justice. In her influential work, Justice and the Politics of Difference, ${ }^{11}$ Young critiques modern, liberal, and distributive theories of justice as reductionist in their "tendency to reduce political subjects to a unity and to value commonness or sameness over specificity and difference," 12 and argues instead that "[o]ppression and domination ... should be the primary terms for conceptualizing injustice." ${ }^{13}$ Young defines injustice as being comprised of interlocking forms of systemic, social conditions of oppression, which she refers to collectively as "the five faces of oppression," namely: exploitation, marginalization, powerlessness, cultural imperialism, and violence. ${ }^{14}$ These "five faces" are described in more detail below.

Young describes the normative form of exploitation at play here in explicitly Marxist terms. She states:

The central insight expressed in the concept of exploitation . . . is that . . [it] occurs through a steady process of the transfer of the results of the labor of one social group to benefit another. The injustice of class division does not consist only in the distributive fact that some people have great wealth while most have little. Exploitation enacts a structural relation between social groups. Social rules about what work is, who does what for whom, how work is compensated, and the social process by which the results of work are appropriated operate to enact relations of power and inequality. ${ }^{15}$

Young's description of exploitation parallels, in legal terms, de jure discrimination. That is, where exploitation enacts economic and material inequality, de jure discrimination enacts, or has enacted at various points in American history, legal inequality - in the forms, for example, of slavery, Jim Crow laws, the marital rape exemption, and, arguably, the military's don'task-don't-tell policy. Moreover, according to Young, because this form of class and economic exploitation is politically, culturally, and socially transmitted and reproduced, its attendant injustices cannot be eliminated simply vis-à-vis the redistribution of goods and resources. Rather, according to her, the elimination of injustice and the bringing about of equality require both the "re-organization of institutions and practices of decisionmaking," as

consequences in the law, but as part of a larger conceptual system designed to make women's subordination seem natural and legitimate."); Catharine A. MacKinnon, Toward a Feminist Theory of the State 215-34 (1989) (providing a feminist critique of formal equality in the context of sex discrimination law).

11. Iris Marion Young, Justice and the Politics of Difference (1990).

12. Id. at 3 .

13. Id. at 9

14. Id. at $37,49-63$.

15. Id. at 49-50 (emphasis added) (citation omitted). 
well as "similar measures of institutional, structural, and cultural change." 16 Similarly, at the sociolegal level, the elimination of injustice requires the elimination of both de jure and de facto discrimination.

With respect to marginalization, Young defines marginals as "people the system of labor cannot or will not use." ${ }^{\prime 17}$ Defined in this way, marginals in the United States, historically and statistically, have been comprised of people with black and brown ${ }^{18}$ skin. However, as Young notes, marginalization does not only impact people of color; it also disempowers the elderly, disabled, young and "unskilled," and single mothers and their children. ${ }^{19}$ Young further points out that oppression caused by marginalization does not dissipate when material necessities like food and shelter are provided. Rather, Young writes:

Even if marginals were provided a comfortable material life within institutions that respected their freedom and dignity, injustices of marginality would remain in the form of uselessness, boredom, and lack of self-respect. . . . Thus while marginalization definitely entails serious issues of distributive justice, it also involves the deprivation of cultural, practical, and institutionalized conditions for exercising capacities in a context of recognition and interaction. ${ }^{20}$

Here again, Young's linking of material oppression in the form of marginalization to ideological oppression in the form of cultural domination and deprivation of agency, is analogous to the co-existence of de jure and de facto discrimination, which is to say both structural/material and ideological/social practices must be eliminated in order to eliminate injustice.

According to Young, in an unjust society, exploitation and marginalization are accompanied by powerlessness, which manifests itself most demonstrably, but not exclusively, as racism and sexism. ${ }^{21}$ Young describes the sorts of injuries associated with such powerlessness as "inhibition in the development of one's capacities, lack of decisionmaking power in one's working life, and exposure to disrespectful treatment because

16. Id. at 53 (emphasis added).

17. $I d$.

18. This category includes not only African Americans, but also American Indians, Latinos, and Asian Pacific Americans, all of whom have been legally and culturally constructed as "outsiders" to American society and culture. See Juan F. Perea et al., Race and Races: Cases and Resources for A Diverse AMERICA 91-428 (2000) (examining at length the varying histories of discrimination suffered by communities of color in the United States).

19. Young, supra note 11, at 53.

20. $I d$. at 55 (emphasis added).

21. Id. at 58 . 
of the status one occupies." 22 In other words, "[i]n daily interchange women and men of color must prove their respectability."23

This kind of powerlessness also describes the attendant psychic and sociocultural harms of both de jure and de facto forms of discrimination. The subordination of minorities and women, while perhaps lessened in some respects, does not disappear simply because the state no longer legally sanctions egregious forms of discrimination, for the law, as it is understood by and imposed on a nation's citizens, plays an essential role in shaping that nation's culture and values. Moreover, culture responds slowly to legal change (and vice versa), even momentous legal changes such as those resulting from civil rights and women's movements of the nineteenth and twentieth centuries. ${ }^{24}$ And, where blatant forms of white and male supremacy were once reified by the law and its often violent and brutal enforcement, the legacies of those legal forms of domination persist in material and ideological ways, in the form of what Young describes as powerlessness and as cultural imperialism (discussed further infra). These material, ideological, and, hence, cultural, legacies are much more difficult to transform because the myriad apparatuses of their transmission lack the purportedly transparent structure and process of legal reform. ${ }^{25}$

Cultural imperialism is both unique and essential to the projects of dominance because of its specifically ideological nature and function. Cultural imperialism is the "universalization of a dominant group's experience and culture, ... its establishment as the norm . . . [and] as representative of humanity as such."26 This normalization of the dominant group's experiences and culture is dialectical in that it interprets and constructs minority and

22. $I d$.

23. $I d$.

24. Here, I refer to early feminist movements for women's suffrage, reproductive, and economic rights, and to early Black resistance and abolitionist movements against slavery. See generally Lerone Bennett, Jr., Before the Mayflower: A History of Black America (Penguin Books 5th ed. 1984) (1962); Unequal Sisters: A Multicultural Reader in U.S. Women's History (Ellen Carol DuBois \& Vicki L. Ruiz eds., 1990).

25. In his well known essay, Ideology and Ideological State Apparatuses (Notes Towards an Investigation), Louis Althusser introduced his concept of the "ideological state apparatus," or, the "ISA." Louis Althusser, Ideology and Ideological State Apparatuses (Notes Towards an Investigation), in LENIN AND PHILOSOPHY AND OTHER Essays 127-86 (Ben Brewster trans., 1971). In his essay on ISAs, Althusser theorized about "the reproduction of the conditions of production" and hegemonic ideology vis-à-vis, in part, the private domains of: "the religious ISA (the system of the different churches) . . , the family ISA, the legal ISA, the political ISA (the political system, including the different Parties) . . . , the communications ISA (press, radio and television, etc.), [and] the cultural ISA (Literature, the Arts, sports, etc.)." Id. at 127, 143.

26. Young, supra note 11, at 59 (emphasis added). 
"outsider"27 groups as "the Other." 28 According to Young, those groups marked as Other "are both marked out by stereotypes and at the same time rendered invisible. The stereotypes confine them to a nature which is often attached in some way to their bodies, and which thus cannot easily be denied. These stereotypes so permeate the society that they are not noticed as contestable." ${ }^{29}$ In other words, cultural imperialism works brilliantly as a mechanism of oppression because of its dialectical rendering not only of the normal and the Other, but also of the Other as both invisible yet completely knowable —or "essentialized" 30 - to the dominant group. Cultural imperialism, and essentialism in particular, have been thoroughly explored by critical race theorists, feminist legal theorists, and scholars of cultural studies. ${ }^{31}$

27. Here, I turn to a phrase originated by Richard Delgado, whose writings form part of critical race scholarship's core. He defines "outgroups" as "any group whose consciousness is other than that of the dominant one." Richard Delgado, Storytelling for Oppositionists and Others: A Plea for Narrative, 87 Мich. L. Rev. 2411, 2412 n.8 (1989). I use the term "outsiders" to refer to individual members of outgroups. For an excellent and concise discussion of how outsider scholarship and "outlaw" texts contribute to legal scholarship, see Kristin Brandser Kalsem, Looking for Law in All the "Wrong" Places: Outlaw Texts and Early Women's Advocacy, 13 S. CAL. Rev. L. \& Women's Stud. 273, 278-80 (2004).

28. Young, supra note 11, at 59 (emphasis added). See also Stuart Hall, The Spectacle of the 'Other, 'in Representation: Cultural Representations and Signifying Practices 223, 239 (Stuart Hall ed., 1997) (discussing how slave trade, European colonization of Africa, and post-World War II migration from "Third World" to Europe and North America impacted development of the racialized "Other," and created "repertoires of representation and representational practices which have been used to mark racial difference and signify the racialized 'Other' in western popularculture"); ANNE MCCLINTOCK, Imperial Leather: Race, Gender, and Sexuality in the Colonial Contest (1995) (analyzing representations set forth in novels, advertising, poetry, and mass commodity spectacle through feminist, post-colonial, and psychoanalytic theoretical lenses, to argue that categories of race, gender, and class do not exist in isolation, but emerge in intimate relation to one another); EDWARD W. SAID, ORIENTALISM 3 (1978) [hereinafter ORIENTALISM] (describing Orientalism—a specific discursive iteration of the Other-as a "Western style for dominating, restructuring, and having authority over the Orient"; further, Orientalism names the "enormously systematic discipline by which European culture was able to manage-and even produce - the Orient politically, sociologically, militarily, ideologically, scientifically, and imaginatively during the post-Enlightenment period," through European colonialism in the Middle East; in theorizing Orientalism, Said also demonstrates that "European culture gained in strength and identity by setting itself off against the Orient as a sort of surrogate and even underground self.").

29. Young, supra note 11, at 59 .

30. Id. See also Feminist Legal Theory: An Anti-Essentialist Reader 5 (Nancy E. Dowd \& Michelle S. Jacobs eds., 2003) (defining essentialism as that which "demonstrates an understanding of gender based only on the lived experience of middle-class white women"); Angela P. Harris, Race and Essentialism in Feminist Legal Theory, 42 StAN. L. ReV. 581, 585 (1990) (defining "gender essentialism" as "the notion that a unitary, 'essential' women's experience can be isolated and described independently of race, class, sexual orientation, and other realities of experience").

31. See, e.g., Hall, supra note 28 , at 225-26 (exploring the representational practice of "stereotyping" and "whether there can be an effective [and critical] "politics of representation"”); EDWARD W. SAid, Culture AND IMPER IALISM (1993) (examining underlying representations of imperialism in 
Violence is the last component of Young's theory of oppression and injustice. According to her, "[w]hat makes violence a face of oppression is ... the social context surrounding [such acts of violence], which makes them possible and even acceptable. What makes violence a phenomenon of social injustice, and not merely an individual moral wrong, is its systemic character, its existence as a social practice." 32 That is, violence as a social practice can be understood as the most forceful response not only to outsiders' resistance to cultural hegemony, but also to their institutional advancement resulting from the removal of structural forms of domination, that is, of de jure discrimination. ${ }^{33}$ Systemic acts of violence-for example in the forms of hate crimes and sexual and/or racial harassment—-keep the Other in its place when it has advanced to or beyond a certain point in various contexts, such as at work or in school, thereby "taking away" perceived entitlements theretofore reserved for those in the majority.

\section{B. Antidiscrimination Principles}

\section{Critical Race Theory and the Five Faces of Oppression}

To be committed to equality and justice, then, is to be committed to the elimination of each of Young's five faces of oppression, which, for purposes of this Article, requires an explication and understanding of how conventional antidiscrimination jurisprudence addresses and/or fails to address these five faces, individually and collectively. First, with respect to exploitation in the workplace, traditional civil rights laws were designed to change the "[s]ocial rules about what work is" ${ }^{\prime 34}$ by removing structural barriers to workplace opportunity. In more broad-ranging terms, civil rights laws aim to integrate American social and working life by altering our notions about "who does what for whom," and "how work is compensated." 35 But, while civil rights laws have removed some barriers and impacted some decision-making

nineteenth and twentieth century English and French literature, and analyzing works by authors such as Jane Austen, Rudyard Kipling, Joseph Conrad, Albert Camus, and E.M. Forster); ORIENTALISM, supra note 28.

32. Young, supra note 11, at 61-62 (emphasis added).

33. See id. at 63 ("The culturally imperialized may reject the dominant meanings and attempt to assert their own subjectivity, or the fact of their cultural difference may put the lie to the dominant culture's implicit claim to universality. The dissonance generated by such a challenge to the hegemonic cultural meanings can also be a source of irrational violence.").

34. Id. at 50 .

35. Id. 
practices in some hiring and promotion contexts, they have done little to address de facto discrimination. Arguably, antidiscrimination laws have reified marginalization, powerlessness, and/or cultural imperialism by failing to address in any substantive way "the social process by which the results of work [and work itself] are appropriated." ${ }^{36}$ While the enforcement of civil rights laws has resulted, in distributive terms, in some (slight) diversification of the middle, upper-middle, and elite classes, it has not lessened the discursive harm associated with marginalization, powerlessness, and cultural imperialism. As critical race theorists have been pointing out for decades, on a day-to-day basis "women and men of color must [continue to] prove their respectability." ${ }^{37}$ Civil rights laws have done very little to dispel, for example, well-established racial and gender stereotyping — or "scripting" 38 — of people of color and women, particularly in the workplace.

Critical race theorists have provided important insights into the ways in which antidiscrimination laws not only have failed to address, but also have further entrenched, ideological and thus material forms of discrimination. According to legal scholars such as Kimberlé Crenshaw, Charles Lawrence, Angela Harris, Mari Matsuda, Richard Delgado, Catharine MacKinnon, Alan David Freeman, and Neil Gotanda - among many others - this is due to antidiscrimination laws' wholesale adoption of neo-liberal, or more aptly, neoconservative, conceptions of equality. ${ }^{39}$ Crenshaw, for example, has identified

36. Id. (emphasis added).

37. Id. at 58. See, e.g., Devon W. Carbado \& Mitu Gulati, Conversations at Work, 79 Or. L. Rev. 103 (2000) (examining relationships between stereotyping and workplace conversations, workplace identity, and workplace discrimination); Katheryn K. Russell, "Driving While Black": Corollary Phenomena and Collateral Consequences, 40 B.C.L. REv. 717, 721-25 (1999) (demonstrating how everyday phenomenon related to racial profiling — such as "walking," "idling," "standing," and "shopping”- while black, results in the reification of mythic Black criminality).

38. See Videotape: Ethnic Notions (Marlon Riggs 1987); Videotape: Color Adjustment (Marlon Riggs 1991). In Ethnic Notions and Color Adjustment, two pathbreaking public television documentaries, the late poet and filmmaker, Marlon Riggs, explored the ways in which African American identities historically have been "scripted" through their limited and often degrading representations in various forms of popular culture.

39. See Kimberlé Williams Crenshaw, Race, Reform, and Retrenchment: Transformation and Legitimation in Antidiscrimination Law, 101 HARV. L. REV. 1331 (1988) (discussed infra at note 55); Charles R. Lawrence III, The Id, the Ego, and Equal Protection: Reckoning with Unconscious Racism, 39 STAN. L. REV. 317 (1987) (critiquing the intent requirement in constitutional discrimination jurisprudence as ahistorical and decontextual); Angela P. Harris, Equality Trouble: Sameness and Difference in Twentieth-Century Race Law, 88 CAL. L. REv. 1923 (2000) (arguing that sameness and difference frameworks of equality elide the central issue of power (i.e., who sets standards of sameness and difference, thereby making freedom and justice difficult, if not impossible, to obtain without development of alternative equality frameworks)); Mari J. Matsuda, Forward: McCarthyism, the Internment and the Contradictions of Power, 40 B.C. L. Rev. 9, 9-10 (1998), 19 B.C. Third World L.J. 9, 9-10 (1998) ("The [Japanese 


\section{the foundational differences between expansive and restrictive views of equality. The expansive view:}

stresses equality as a result, and looks to real consequences for [subordinated classes, such as] African Americans. It interprets the objective of antidiscrimination law as the eradication of the substantive conditions of Black subordination and attempts to enlist the institutional power of the courts to further the national goal of eradicating the effects of racial oppression. ${ }^{40}$

This stands in contrast to the restrictive view of equality, which:

treats equality as a process, downplaying the significance of actual outcomes. The primary objective of antidiscrimination law . . . is to prevent future wrongdoing rather than to redress present manifestations of past injustice. "Wrongdoing," moreover, is seen primarily as isolated actions against individuals rather than as a societal policy against an entire group. Nor does the restrictive view contemplate the courts playing a role in redressing harms from America's racist past, as opposed to merely policing society to eliminate a narrow set of proscribed discriminatory practices. ... In sum, the restrictive view seeks to proscribe only certain kinds of subordinating acts, and then only when other interests are not overly burdened. ${ }^{41}$

This restrictive view, coupled with a doctrinal emphasis in the law on the "perpetrator perspective" and on the perpetrator's intent, ${ }^{42}$ function to (re)cast the Other, who is ostensibly protected under the law, as presumptively and

\footnotetext{
American] internment story both presages and diverges from the Cold War story, making way for our contemporary map of power: racism and class privilege dancing unscathed behind the curtains marked 'formal equality' and 'free market.' ... There is a Constitutional promise of liberty and equality, violated in both instances [of McCarthyism and internment], which we have yet to uphold."); Richard Delgado, The Imperial Scholar: Reflections on a Review of Civil Rights Literature, 132 U. PA. L. REv. 561, 566 (1984) (critiquing then-existing civil rights scholarship as being overwhelmingly authored by liberal white male academics and revealing "white scholars' systematic occupation of, and exclusion of minority scholars from, the central areas of civil rights scholarship"); MACKINNON, supra note 10, at 234 ("The mainstream law of equality assumes that society is already fundamentally equal. It gives women legally no more than they already have socially, and little it cannot also give men."); Alan David Freeman, Legitimizing Racial Discrimination Through Antidiscrimination Law: A Critical Review of Supreme Court Doctrine, 62 MINN. L. REV. 1049, 1052-57 (1978) (arguing that antidiscrimination law legitimizes discrimination because it focuses doctrinally on the intent of the alleged perpetrator, rather than on the systemic conditions of racial subordination and the condition of the victim); Neil Gotanda, A Critique of "Our Constitution is ColorBlind," 44 Stan. L. Rev. 1 (1991) (discussed infra at Part I.B.2.).

40. Crenshaw, supra note 39, at 1341; see also Young, supra note 11, at 9 (arguing that injustice should be conceptualized primarily in terms of oppression and domination).

41. Crenshaw, supra note 39, at 1342 (footnote omitted) (citing DerRick A. Bell, JR., RACE, RACISM AND AMERICAN LAW § 1.12, at 41 (2d ed. 1981)).

42. See Freeman, supra note 39, at 1052-57.
} 
essentially non-credible and, as the late Jerome Culp put it, as the "(perpetually possible) subject of discrimination." ${ }^{43}$

\section{Imploding the Myth of Colorblindness}

Speaking more specifically to constitutional jurisprudence on racial discrimination, Professor Gotanda has imploded the myth of constitutional colorblindness, exposing it as the juridical legitimation of white supremacy, veiled in the rhetoric of neutrality and colorblindness. ${ }^{44}$ In his work, Gotanda reveals certain normative techniques that the Supreme Court has employed, all of which function, intentionally or not, to situate racial minorities as Other to the white majority. For example, in his analysis of the way in which the Court historically has distinguished between actionable public discrimination and non-actionable private discrimination, Gotanda demonstrates how the Court "obscures the contingent and political character of the initial designation [of public vs. private]." ${ }^{45}$ As such, writes Gotanda, "subsequent challenges [by outsiders] to the subordinating effects of such a 'neutral' distinction are then criticized as 'political.","46

Gotanda also exposes the Supreme Court's tendency to decontextualize and deny the material conditions of racial oppression through its technique of racial nonrecognition:

[Nonrecognition] addresses the question of race, not by examining the social realities or legal categories of race, but by setting forth an analytical methodology. This technical approach permits a court to describe, to accommodate, and then to ignore issues of subordination. This deflection from the substantive to the methodological is significant. Because the technique appears purely procedural, its normative, substantive impact is hidden. Color-blind application of the technique is important because it suggests a seemingly neutral and objective method of decisionmaking that avoids any consideration of race. ${ }^{47}$

This “discounting [of] 'racialness,"” which Gotanda also claims is inconsistent with the philosophical underpinnings of American constitutionalism, ${ }^{48}$ results

43. Jerome M. Culp, Jr. et al., Subject Unrest, 55 Stan. L. Rev. 2435, 2444 (2003) (book review).

44. Specifically, Gotanda writes, "A color-blind interpretation of the Constitution legitimates, and thereby maintains, the social, economic, and political advantages that whites hold over other Americans." Gotanda, supra note 39, at 2-3. In other words, a color-blind interpretation of the Constitution legitimates white supremacy.

45. Id. at 13 .

46. $I d$.

47. Id. at 17 .

48. Id. at 21 . 
in the "repression and denial of racial subordination." on Gotanda's critique, constitutional antidiscrimination jurisprudence is merely declaratory, for it denies the existence of the interlocking material and ideological conditions of racial subordination altogether.

\section{Responding to Ideological "Violence"}

In its most devastating and literal forms, violence- the last of Young's five faces of oppression - manifests as hate crimes perpetrated by those in the majority (Whites, males, and heterosexuals) against women and racial and sexual minorities. Although ongoing struggles in state and municipal legislatures over whether the hate crime should even exist belie an unstable social and political commitment to the elimination of this aspect of oppression, the hate crimes "movement" has met with some limited success. ${ }^{50}$ Without minimizing the profound effect of hate crimes, this Article concerns itself more specifically with the less physical and more psychological manifestations of subordinating violence, that is, with forms of racial and sexual harassment in the workplace that are deemed acceptable because they conform to acceptable stereotypes of particular social groups. For courts have held that some form of harassment of women in traditionally male spaces, ${ }^{51}$ people of color in traditionally white spaces,${ }^{52}$ and lesbian, gay, bisexual, and transgendered persons in traditionally straight spaces $^{53}$ is permissible. Additionally these courts have found that harassment of such persons is actionable only when it rises to a standard of pervasive and extreme hostility, which standard courts have developed, nonsensically, by deferring in most cases to those in the majority. ${ }^{54}$

49. Id. at 21-23.

50. Legislative and community-based attempts to deal with this kind of violence have been welldocumented by legal and other scholars. See, e.g., Jeannine Bell, Policing Hatred: Law Enforcement, Civil Rights, AND HATE Crime (2002) (exploring impact of hate crime laws from the perspective of police officers and prosecutors enforcing them, taking into account not only impact on victims, but on defendants' first amendment rights, and on society as a whole).

51. See, e.g., Harris v. Forklift Sys., Inc., 510 U.S. 17 (1993); Meritor Sav. Bank v. Vinson, 477 U.S. 57 (1986); Hicks v. Gates Rubber Co., 833 F.2d 1406 (10th Cir. 1987); Parton v. GTE North, Inc., 802 F. Supp. 241 (W.D. Mo. 1991).

52. See, e.g., Ramsey v. Henderson, 286 F.3d 264 (5th Cir. 2002); Hicks, 833 F.2d 1406; Gharzouzi v. N.W. Human Servs. of Pa., 225 F. Supp. 2 d 514 (E.D. Pa. 2002).

53. See, e.g., Feingold v. New York, 366 F.3d 138 (2d Cir. 2004); Patches v. City of Phoenix, No. 02-15408, 2003 WL 21206120 (9th Cir. May 12, 2003); Kay v. Independence Blue Cross, 91 Fair Empl. Prac. Cas. (BNA) 1559 (E.D. Pa. 2003).

54. See supra notes 51-53. 


\section{Re-Theorizing Discrimination: Carbado and Gulati's "Working Identity"}

Critical race theory and Young's theory of oppression also overlap in that both lead to the conclusion that legal applications of neo-conservative interpretations of equality cannot possibly succeed in eliminating inequality because those interpretations assume the absence in society of hegemonic racial power and subordination. ${ }^{55}$ Unfortunately, it appears that civil rights discourse, with some limited exception, ${ }^{56}$ has moved increasingly toward an exclusive adoption of the restrictive view of equality, in that the law names as discriminatory, with only a very few exceptions, discrete sets of decontextualized acts that are inflicted on a victim by an atomistic perpetrator who intends to do harm. ${ }^{57}$ Notwithstanding the availability of the "disparate

55. See Crenshaw, supra note 39, at 1344-46. "[T] o believe ... that color-blind policies represent the only legitimate and effective means of ensuring a racially equitable society, one would have to assume not only that there is only one 'proper role' for law, but also that such a racially equitable society already exists." Id. at 1344.

56. The Supreme Court's recent decision in Grutter v. Bollinger, 539 U.S. 306 (2003), in which it upheld the University of Michigan Law School's race-conscious admissions policy and affirmed that diversity is a compelling state interest for equal protection purposes, offers some hope in this regard, but only a very small amount. For example, Justice O'Connor, writing for the majority in that case, wrote that: "Context matters when reviewing race-based governmental action under the Equal Protection Clause. [citations omitted]. ... Not every decision influenced by race is equally objectionable ...." Id. at 327. The Court also accepted the Law School's argument that its goal of assembling a diverse student body that includes a "critical mass" of students of color - a concept that is itself based on the anti-essentialist idea that students of color do not necessarily share a unitary perspective-did not constitute a quota. $I d$. at 329-36. However, the Court's reasoning in upholding the Law School's policy is troubling in other ways. For example, in rendering its opinion, the Court did not reconsider in any way its neo-conservative dream of the "colorblind society." See id. at 349-78 (Thomas, J., dissenting). Just as troubling is the Court's reasoning regarding the value of diversity, which helps to break down stereotypes of minorities, which presumes that minority students are valuable first and foremost for the educational benefits they will confer on their majority classmates, and that they have an obligation to confer those benefits in the first place. While it is true that we all benefit from the breaking down of stereotypes, students of color are far more susceptible to being typed in specific and particularly negative ways by their peers, teachers, and potential employers than are majority students; consequently, they must do more to "diminish[ ] the force of such stereotypes" than their majority counterparts. See id. at 333; see also Angela Onwuachi-Willig, Just Another Brother on the SCT: What Justice Clarence Thomas Teaches Us About the Influence of Racial Identity, 90 IowA L. REV. _ (forthcoming 2005) (arguing that despite allegations of his "anti-black" news, Justice Thomas's is grounded specifically in black conservative thought).

57. See Critical Interventions, supra note 2, at 1059-61 (criticizing the perpetrator perspective of racial discrimination, which views discrimination as a discrete set of acts inflicted on the victim by the perpetrator, and arguing that antidiscrimination law's focus on intentional discrimination is a manifestation of the perpetrator perspective). 
impact" claim under Title VII, which has "all but vanished from the scene," 58 the law does not define discrimination as a set of culturally-acceptable and institutionally-perpetuated social practices rooted in the legacies of white supremacy and male dominance. This is to say that antidiscrimination law, through its adoption of restrictive views of equality, ignores the discursive aspects of Young's faces of oppression. Legally speaking, in other words, antidiscrimination law simply does not address de facto discrimination.

Professors Devon Carbado and Mitu Gulati have made the case for an antidiscrimination discourse that explicitly takes account of these three disregarded faces of oppression. Their theory of "working identity" explores the behavioral concepts of signaling and identity performance ${ }^{59}$ in the employment context and posits that members of outsider groups in the workplace often must do extra identity work because those outsiders correctly perceive themselves as subject to negative stereotypes in the workplace. ${ }^{60}$ Put another way, members of outsider groups in the workplace often feel compelled to perform and signal "loudly" against negative identity-related stereotypes in order to prevent discrimination based on those stereotypes.

58. Martha Chamallas, Title VII's Midlife Crisis: The Case of Constructive Discharge, 77 S. CAL. L. Rev. 307, 348 \& n. 163 (2004) (citing John J. Donohue III \& Peter Siegelman, The Changing Nature of Employment Discrimination Litigation, 43 Stan. L. Rev. 983, 989 (1991), for the proposition "that disparate impact cases accounted for less than two percent of the federal employment discrimination caseload in 1989"). A plaintiff bringing a disparate impact claim under Title VII must show that a facially neutral job requirement or policy has a disproportionate impact on a protected group and that the requirement or policy is not related to job performance. 42 U.S.C. $\$ 2000 \mathrm{e}-2(\mathrm{k})(2000)$ (burden of proof in disparate impact cases); see, e.g., Dothard v. Rawlinson, 433 U.S. 321, 331-33 (1977). Unlike in a disparate treatment claim, once a plaintiff shows disparate impact, the burden shifts to the employer to either refute the elements of the plaintiff's case, or demonstrate that the facially neutral requirement or policy is justified by a business necessity. See Griggs v. Duke Power Co., 401 U.S. 424, 431 (1971).

59. Devon W. Carbado \& Mitu Gulati, Working Identity, 85 Cornell L. Rev. 1259, 1260-61 (2000) (explaining that in attempting to "signal" difficult-to-observe identity characteristics, i.e., to perform identity, individuals in the workplace "have an incentive to work their identities in ways that suggest to the employer what otherwise might not be readily apparent," e.g., by mentioning in casual conversation with a co-worker how tired one is from working late the night before, or by sending a work-related email to a supervisor late at night to demonstrate the same); David Charny \& G. Mitu Gulati, Efficiency-Wages, Tournaments, and Discrimination: A Theory of Employment Discrimination Law for "High-Level" Jobs, 33 HARV. C.R.-C.L. L. REV. 57, 89-95 (1998) (developing, in part, an economic analysis of employment discrimination that "shows how discrimination perpetuates itself, in part, by influencing the career strategies that workers adopt in response to discrimination" and "explains the interaction between strategies that workers adopt and corresponding modes of evaluation (e.g., in responding to noisy signals)"); see also Gertrud M. Fremling \& Richard A. Posner, Status Signaling and the Law, with Particular Application to Sexual Harassment, 147 U. PA. L. REv. 1069, 1069-70 (1999) (discussing generally the phenomenon of "status signaling").

60. Carbado \& Gulati, supra note 59, at 1262. 
One of the hypotheticals Carbado and Gulati use to demonstrate their thesis that "performing identity is work," involves a first-year, black, male law professor teaching about Terry stops in a criminal procedure course. ${ }^{61}$ In this regard, they explore the professor's "subject unrest," ${ }^{62}$ stating that "[t]he possibility exists that stereotypes ... will be at odds with stated or unstated criteria that (he thinks) the institution values. ${ }^{963}$ Thus, the first-year black law professor, in making his pedagogical choices about whether to use the Socratic method or alternate forms of teaching - such as small group work or lecturing-must consider racial scripting in a way that his white male colleagues do not. Even if he wants to use small groups or to lecture on some topics because he has carefully considered the pedagogical value of those teaching methods over the Socratic method, he must consider and risk whether choosing to employ them will result in the reinforcing of stereotypes - of his being disorganized, intellectually soft, and lacking in rigor- that students and colleagues might attach to him as a black man using alternate teaching methods. $^{64}$ If the professor decides to explicitly discuss race in his teaching of the Terry doctrine in his criminal procedure class, he also must consider and risk whether doing so will result in teaching evaluations, especially at institutions where the student body is mostly white, that fault him for being "obsessed with race" and, thus, not objective. ${ }^{65}$

Carbado and Gulati also deepen Gotanda's critique of colorblindness, defining the "colorblind norm" as one where "whites cannot intentionally discriminate against people of color based on race. ... The colorblind idea does not, however, place an affirmative duty on whites to interact with people of color, or a negative duty to dissociate and disidentify themselves from whites." ${ }^{\prime 66}$ Here, they use a law firm lunch hypothetical, where a group of Latina/o associates having lunch together appears to insiders as racially clannish, non-collegial, and "undermining [of] the law firm's colorblind ideal, ${ }^{, 67}$ whereas a group of white associates lunching together piques very

61. Id. at $1279-88$.

62. "Subject unrest" refers, in part, to "the tension between first-person and third-person accounts of the world - between the 'objective' and the 'subjective," and to "the problem of identity." Culp et al., supra note 43 , at $2436-37$.

63. Carbado \& Gulati, supra note 59, at 1279-80. Specifically, the hypothetical demonstrates all the "extra" work the professor must do in choosing to use the Socratic teaching method and in teaching Terry v. Ohio, 392 U.S. 1 (1968). See id. at 1279-88.

64. Id. at 1281-83. Anecdotally, this is extra identity work that many women also incur.

65. Id. at $1283-84$.

66. Id. at $1285-86$.

67. Id. at 1286 . 
little interest at all, positive or negative. The important point here relates to the unidirectional nature of the colorblind norm:

The colorblind norm does not require whites to avoid other whites or to associate with people of color. This norm does, however, require people of color to avoid other people of color (the negative racial duty) and to associate with whites (the affirmative racial duty). In fact, the colorblind norm operates as a color conscious burden. Colorblindness, therefore, does not actually mean colorblindness. Specifically, it racially regulates the workplace association of people of color, but not those of white people. A colorblind workplace norm requires people of color, but not white people, to think and be careful about their racial associations. ${ }^{68}$

Therein lies the extra work of colorblindness, particularly with respect to employees of color in predominantly white work environments. ${ }^{69}$

While Carbado and Gulati limit their discussions of working identity theory to the ways in which it negatively impacts people of color and women, the difficulties of performing one's identity can also attach to insiders who have aligned themselves with perceived outsider "issues." Recognizing this possibility is important because it demonstrates how whiteness, maleness, and straightness are also socially constructed categories of race, gender, and sexuality, and how the construction of these insider categories feeds cultural hegemony. Take, for example, Andrew, a white, straight male whose teaching and scholarly interests are in family law, constitutional law, critical race theory, and feminist legal theory. Andrew is a second-year law professor at a law school whose students are predominantly white, and whose faculty is predominantly white and male. Because of the general disinterest of other faculty members, Andrew advises the Black Law Students Association. Also, because there is no corresponding association for gay, lesbian, bisexual, and transgender law students, Andrew has affixed a rainbow sticker to the outside of his door, to signal his openness to and support of students who are sexual outsiders at the school.

68. Id. at $1287-88$.

69. In their paper, Carbado \& Gulati also discuss some "[a]dditional costs of working identity," such as: the practice of identity denial, whereby people of color negotiate their racial identities for the express purpose (in their minds) of ensuring that in siders feel at ease around them; the compromising of one's selfidentity as less "political" in order to signal a negation to insiders of stereotypes of the strident minority; and the dilemma of what to do about racial humor, which, based upon the reaction of the outsider employee, can mark her as overly sensitive and not a team player. $I d$. at 1288-91. Moreover, they describe the risks involved in working identity, as "[i]dentity performances can backfire," particularly in light of the fact that many stereotypes attaching to, for example, Asians are interconnected. Id. at 1291. For example, if a black woman attempts to negate a stereotype of laziness by working extra long hours at the law firm, insiders might attach the flipside stereotype that the reason she must work so many hours is because she is intellectually incompetent. See id. at 1292. 
Obviously, because of his commitment to diversity and the apparent disinterest in diversity on the part of his colleagues, Andrew is already doing extra identity-related work in that he is advising several student groups and individual students, on top of his teaching, scholarship, and other institutional service. Moreover, because the dean of the school is concerned about recruiting more minority, female, and/or gay and lesbian faculty - in small part so that the burden of the work Andrew is doing can be spread around a bit - the dean has assigned Andrew to the faculty appointments committee, widely regarded as the school's most "powerful" and work-heavy committee. Based on Andrew's assignment to this committee so early in his career, a few of his senior colleagues begin to suspect his political relationship with the dean. Moreover, they cannot understand why Andrew chooses to commit time and energy to issues relating to race, gender, and sexuality. By virtue of his political alignment with people of color, women, and sexual minorities, Andrew is soon marked as an outsider himself, as probably gay and as a sort of "race [and gender] traitor"70 (although he is not explicitly termed as such). Finally, that Andrew would choose to engage in this kind of work, instead of devoting more time to his scholarship, will probably not help his case when it comes time for him to apply for promotion and/or tenure.

In terms of identity scripting, Andrew could have performed his white male identity rather successfully in myriad ways without incurring the kind of risk he has now incurred through his outsider alignment. Unlike people of color and women, for example, who are expected stereotypically to teach and write in a few areas and to commit to certain institutional priorities, ${ }^{71}$ Andrew could have chosen to teach almost anything in the curriculum including courses like family law, feminist jurisprudence, and/or critical race theory. However, having chosen to teach and write in all of those areas, Andrew is now excepted as an "Other," defeating the presumption that he is an insider. And, although due to his alignments Andrew must perform much of the extra identity work that outsiders are expected (and often want) to do, he probably still does not have to consider whether his breaking his students into small groups in class will reinforce a stereotype of intellectual softness or laziness because such stereotypes do not attach to white male professors. The key difference between Andrew, an aligned outsider, and "immutable" outsiders,

70. See Race Traitor 9-14 (Noel Ignatiev \& John Garvey eds., 1996) (arguing that whiteness is socially constructed to perpetuate racial dominance and, thus, should be dismantled in favor of a "New Abolitionism" movement).

71. For example, women are often expected to teach and/or write in the areas of family law, employment discrimination, and/or feminist legal theory. 
is that his conduct dictates his designated status as outsider, rather than his status dictating his conduct, which is generally the case for immutable outsiders.

Thus, identity work burdens outsiders and, to a lesser extent, insiders aligned with pre-designated outsider interests, not only in that this work requires them to do more on a physical, mental, and emotional level, but also because it causes them to incur work and identity-related risks that their insider counterparts do not incur. ${ }^{72}$ The shaping of workplace incentives to perform or counter-perform one's scripted identity are at the heart of Carbado and Gulati's work. Their most important intervention occurs when they argue that "both the nature of the work and the pressure to do it, the "working identity' phenomenon, is a form of employment discrimination." ${ }^{\text {73 }}$ They critique the law's failure thus far to recognize this form of discrimination and for its failure to distinguish between discrimination based on racial status, the linchpin of our current antidiscrimination paradigm, and that based on racial conduct. ${ }^{74}$ Carbado and Gulati state:

$[\mathrm{T}] \mathrm{o}$ the extent that antidiscrimination law ignores identity work, it will not be able to address 'racial conduct' discrimination. Racial conduct discrimination derives, not simply from the fact that an employee is, for example, phenotypically Asian American (i.e., [his] racial status) but also from how [he] performs [his] Asian American identity in the workplace (i.e., [his] racial conduct) ${ }^{75}$

Understanding the difference between discrimination based on racial status and that based on racial conduct is key to understanding how Carbado and Gulati's working identity theory addresses the material and ideological - the de jure and de facto-aspects of Young's theory of oppression. ${ }^{76}$ Young's theorizing of the marginalized and powerless as those who must "prove their respectability" because of the status they occupy, ${ }^{77}$ parallels Carbado and Gulati's theory of working identity. Both theories seek to problematize the meaning of discrimination by exposing cultural and social linkages between, in the case of a person of color, her racial conduct - conduct that is always susceptible to comparison with a set of

72. See Carbado \& Gulati, supra note 59 , at 1262.

73. Id. (emphasis added).

74. Id. at $1262-63$.

75. Id.

76. For an excellent analysis of related theories of sex-specific trait discrimination, see Kimberly A. Yuracko, Trait Discrimination as Sex Discrimination: An Argument Against Neutrality, 83 Tex. L. REV. 167 (2004).

77. YounG, supra note 11, at 58. 
presumed outsider stereotypes that are, in the end, never respectable - to her racial status, to which those stereotypes are attached in the first place. That a non-minority need not negotiate his racial status by altering his conduct - that he need not do (but could choose to do, as with Andrew) the extra identity work that a minority is expected to do-demonstrates just how normalized his culture and experiences are, and the extent to which workplaces function as colonized spaces. ${ }^{78}$

In introducing their theory of working identity, Carbado and Gulati also address at some level all five faces of Young's theory of injustice and oppression. But, as I have written elsewhere, I am not persuaded that equality can be achieved if civil rights law remains the only doctrinal field that expressly aspires to it. $^{79}$ Thus, this Article pushes the boundaries of the important work from which it is derived, by asking: Can and should doctrinal fields outside of the law of employment discrimination and traditional civil rights law aspire toward equality and the elimination of Young's five faces of oppression? And is it appropriate for other areas of the law, particularly those areas regarded as "private," to do so?

\section{Why Consider Public Law Norms?}

In response to the questions just posed, this Article obviously responds affirmatively. This Article's normative project, first taken up in Critical Interventions, posits that the good faith doctrine in contract law furnishes an ideal vehicle by which to test its feasibility, not only because of its definitional potential but also because of its substantive emptiness. ${ }^{80}$ Good faith can and

78. The colonized workspace refers to the complex and inherently hierarchical relationship between any worker/employee and the institution for which s/he works. As Said has written, specifically in the context of the role of the intellectual, this relationship is "never static but always evolving ...." EDwARD W. Said, Representations of the Intellectual 65 (1994). Said's description of the problematic relationship between the scholar-academic, his/her institution, and/or society-at-large is especially illuminating in this regard:

$[T]$ he question remains as to whether there is or can be anything like an independent, autonomously functioning intellectual, one who is not beholden to, and therefore constrained by, his or her affiliations with universities that pay salaries, political parties that demand loyalty to a party line, think tanks that while they offer freedom to do research perhaps more subtly compromise judgment and restrain the critical voice. Id. at 67-68.

79. See Critical Interventions, supra note 2, at 1095.

80. Doctrinally speaking, Ihave argued elsewhere that the good faith doctrine functions in modern contract law more as an analytical proxy for material breach analyses, than as an equitably implied obligation. See Houh, supra note 1. 
should be salvaged, in part by loading it not only with existing notions of fundamental fairness and honesty in fact, but more generally with public law norms that call for the promotion of the model of equality described in Part I of this Article. The more general normative goal of infusing private law with public law norms is controversial to say the least, but not unprecedented. Critical Interventions discussed one set of justifications for the more specific goal of infusing contract law with equality norms; that is, it argued in part that the incorporation of the expansive equality norm into contract law is in part necessitated by the inability of conventional civil rights law to achieve substantive and more expansive notions of sociopolitical equality. ${ }^{81}$ This Part expands upon those and other justifications.

That the implied obligation of good faith should be salvaged by incorporating it with equality norms should be considered seriously, in part because precedent exists for linking public law norms with the private law of contract. With respect to good faith in particular, this private/public law overlap has emerged in its pragmatic form as the claim for tortious breach of good faith claim, which is limited usually - to the extent such claims are recognized at all - to insurance cases. ${ }^{82}$ The tortious breach of good faith claim, as well as the scholarly and doctrinal controversy over whether tort law should be considered private or public in nature, are discussed below. The more general controversy relating to the public/private distinction is discussed infra at Part II.B.

\section{A. The Tort-Contract Overlap}

Over the past five decades, scholarly debate has waxed and waned as to whether tort law, once regarded as belonging firmly to the realm of private law, is really "public law in disguise." as private law because it sought to remedy wrongs between individuals - as opposed to between an individual and the state - by compensating the aggrieved individual, who is empowered to bring suit, rather than by

81. See Critical Interventions, supra note 2, at 1054-95.

82. See Douglas G. Houser, Good Faith as a Matter of Law: The Insurance Company's Right To Be Wrong, 27 TORT \& INS. L.J. 665, 665-66 (1992) (discussing the origination in California of bad faith tort in the insurance context, and noting that at the time of writing, "[t]hirty-five jurisdictions ... appear to recognize a first-party bad faith cause of action.... [while] [f]ourteen states appear to have rejected firstparty 'bad-faith' claims").

83. See generally Leon Green, Tort Law Public Law in Disguise, (Pts. I \& II), 38 Tex. L. Rev. 1, 257 (1959-1960). 
penalizing the tortfeasor. ${ }^{84}$ Some scholars began to recognize, however, that in compensating the aggrieved, judges and juries, through deciding cases and creating and applying tort rules, were in essence also creating social norms, standards, and duties to which citizens could be held, lest they be compelled to compensate those harmed by their breaches of these norms, standards, and duties. ${ }^{85}$ Unlike contractual duties, which for the most part are privately created and ordered by the parties to a particular transaction or series of transactions, tort duties are imposed on all members of society by the specter of the tort claim and judicially-awarded tort damages. ${ }^{86}$ Other scholars have exposed the fundamental role of justice and public policy in major tort law decisions, arguing that tort law is not simply a matter of doctrinal development, but of (sometimes explicit) public policy implementation. ${ }^{87}$ Thus, many scholars began to re-characterize tort law as public law. ${ }^{88}$ This Article follows the more contemporary approach and conceives of tort law as public law, or at the very least, quasi-public law.

The late Professor Grant Gilmore most famously made the case, however tongue-in-cheek, for the linking of tort and contract law in The Death of Contract, ${ }^{89}$ which was based on a series of lectures Gilmore delivered at The Ohio State University Law School in 1970. ${ }^{90}$ In relevant part, through his deconstruction of foundational contracts texts such as Dean Langdell's first casebook and Williston's first treatise on contracts, Gilmore argued that contract law "did not come as the natural result of a continuing case-law development." 91 Rather, Gilmore argued that the likes of Langdell and Williston "invented" contract law in a rather pieced-together and post-modern fashion by making "industrious use of whatever bits and pieces of case law,

84. See John C.P. Goldberg, Twentieth-Century Tort Theory, 91 GEo. L.J. 513, 516-22 (2003) (describing the "traditional account" of tort law, and distinguishing tort from criminal law in that "the power to bring suit against an actor alleged to have ... [committed a tort] resided only in the person or entity who could claim to have been wrongfully injured as a result of the violation, rather than in other persons or a government official"); see also David V. Snyder, Private Lawmaking, 64 Оніо Sт. L.J. 371, 375 (2003) (referring to contract law, tort law, and the law of commercial transactions as "prime examples" of private law).

85. See Goldberg, supra note 84 , at 519-21.

86. See generally id. at 516-21.

87. See Green, supra note 83 , at 269.

88. Notably, one of the co-authors of a leading American contracts casebook recently characterized tort law as public law. See Charles L. Knapp, Taking Contracts Private: The Quiet Revolution in Contract Law, 71 Fordham L. Rev. 761, 765 (2002) (citing Charles L. Knapp et al., Problems in Contract LAw 3 (4th ed. 1999)).

89. Grant Gilmore, The Death of Contract (Ronald K.L. Collins ed., 2d ed. 1995).

90. Id. at xxxi.

91. Id. at 19 . 
could be made to fit the theory." ${ }^{92}$ Gilmore further argued that those like Langdell stamped these cases with the imprimatur of authority by labeling (and teaching) them as the "leading cases.""93 Gilmore's deconstruction of those leading cases and the doctrines and issues they had come to represent-for example, consideration, modification, irrevocable offers, mistake, and promissory estoppel-remains brilliantly illuminating (and highly entertaining). ${ }^{94}$ But, most significantly, Gilmore's analysis continues to call into question the sharp lines we have drawn between private and public law, particularly with respect to contract and tort law. Has contract doctrine, in part through its pervasive incorporation of reliance principles and theories, been (re-)absorbed by tort law? Should it? If not, should contract scholars continue to brighten the line between contract law and tort law, or should attempts be made to blur the line in particular places? Have the courts explicitly addressed these questions and, if so, how?

In Story v. City of Bozeman, ${ }^{95}$ the Supreme Court of Montana explicitly attempted to respond to some of these questions and gave some mixed answers. As in so many contractor disputes, the breakdown in the relationship between the plaintiff-contractor and the defendant-owner began with an error in the bidding specifications issued by the defendant on which the plaintiff had relied in putting together his winning bid. The owner maintained that the contractor knew or should have known about the error and, as such, refused to make any upward modification on the contract price, as demanded by the contractor. Further disputes eventually arose over the quality of the contractor's work and, ultimately, the owner terminated the contract. ${ }^{96}$ The contractor then filed suit alleging breach of contract, bad faith, and defamatory conduct on the part of the owner. ${ }^{97}$

At trial, the jury found that the owner had breached the implied covenant of good faith and fair dealing and awarded the contractor tort damages for breach of good faith in an amount that was more than twenty-five times what it awarded on the breach of contract claim. ${ }^{98}$ This disparity in the tort and contract damages caused the state's high court to become concerned that "the 'tort tail' ha[d] begun to wag the 'contract dog"'; thus, it embarked on a

92. $I d$.

93. See id.

94. See id. at 39-93.

95. Story v. City of Bozeman, 791 P.2d 767 (Mont. 1990).

96. Id. at 769 .

97. Id.

98. Id. at 772 . 
thorough review of the law in order "to make mid-course corrections." court traced the development of the tortious bad faith claim, which is significantly different from the contractual bad faith claim in that punitive or tort damages, and not just contractual expectation damages, may be awarded for tortious breach of good faith. ${ }^{100}$ The claim for tortious breach of good faith originated in (and in most states recognizing such a claim is restricted to) the insurance context. ${ }^{101}$ The court then observed that, like some other states recognizing tortious bad faith claims in the insurance context, Montana had extended the tort of breach of good faith both to employment/wrongful discharge cases, as well as to cases involving a "special relationship" as between the contracting parties. ${ }^{102}$ But, in Nicholson v. United Pacific Insurance Co. ${ }^{103}$ decided five years before Story, the Montana Supreme Court went further than any other jurisdiction by extending the bad faith tort claim to "typical arms-length contracts." 104

Noting that the court, through Nicholson, had taken a position on tortious good faith that had out-reached even California's (then) position, the court reviewed the many ways in which the Montana courts and legislature had begun to delimit and deter "over-use" of the tortious bad faith claim. ${ }^{105}$ For example, in the at-will employment context, courts allowed tortious bad faith claims only when "the employer's objective manifestations give the employee a reasonable belief that he or she has job security."106 In the insurance context, bad faith claims based on the insurer's alleged refusal to settle had to "await determination of the underlying liability issue to prevent prejudice to the insurer." 107 Also, as a general matter, the court had held that the implied obligation of good faith and fair dealing could not be breached unless there was also a breach of contract. ${ }^{108}$ Finally, the Montana legislature banned

99. Id.

100. See Matthew J. Barrett, Note, "Contort": Tortious Breach of the Implied Covenant of Good Faith and Fair Dealing in Noninsurance, Commercial Contracts-Its Existence and Desirability, 60 Notre Dame L. Rev. 510, 510-11 (1985).

101. Courts developed the tortious bad faith claim to enable insureds to sue their insurers for abusive claims settlement practices, particularly because, as a matter of industry custom, insurers contractually reserved in their policies absolute discretionary authority over such settlement practices. Story v. City of Bozeman, 791 P.2d 773 (Mont. 1990) (citations omitted).

102. $I d$. (citations omitted).

103. Nicholson v. United Pacific Ins. Co., 710 P.2d 1342, 1348 (Mont. 1985).

104. Story, 791 P.2d at 773 (citations omitted).

105. Id. at 774-75.

106. Id. at 774 .

107. Id. at 775 .

108. $I d$. 
punitive/tort damages with respect to claims arising out of breach of contract and statutorily adopted a UCC definition of good faith that required "honesty in fact and the observance of reasonable commercial standards of fair dealing in the trade." $" 109$

Based on this history, the Story court limited the position taken by the Nicholson court before it, and held that: "In common contract actions, torttype damages are not available for breach of the implied covenant of good faith and fair dealing. They are, however, available for traditional contractrelated torts such as fraud, fraudulent inducement, and tortious interference with a contract." ${ }^{110}$ In addition to these contract-related torts, the court held that tort damages would still be available for breach of good faith claims in "exceptional circumstances," such as with respect to contracts involving "special relationships." "111

Story represents the majority position that, outside of "contorts" such as fraudulent inducement, misrepresentation, and tortious interference, tortious bad faith claims are limited to "special relationship" contracts cases, which might involve insurers and insureds, employers and employees, and fiduciaries and beneficiaries. The court's tracing of the tortious bad faith claim's history and its categorical approach to such claims illuminate the tort-contract overlap. The Story court's discussion of well-established contort claims and its restriction of other tortious bad faith claims to those involving special relationships not only acknowledges the historical linkages between tort and contract claims, but also reveals the core difference between the tort and contract claim based on the same set of facts: the extent of available damages. The problem with awarding tort damages for contract claims, according to the court and numerous commentators, is that "the specter of tort damages upsets the concept of efficient breach." "112 Numerous other scholars, however, have critiqued the concept of efficient breach, particularly as it relates to the availability of tort damages in breach of contract cases involving emotional distress. ${ }^{113}$

109. Id.

110. Id. at 776 (emphasis added).

111. $I d$.

112. Id. at 774. "Efficient breach" occurs when:

in some cases a party ... break $[\mathrm{s}]$ his contract simply because his profit from breach would exceed his profit from completion of the contract. If it would also exceed the expected profit to the other party from completion of the contract, and if damages are limited to the loss of that profit, there will be an incentive to commit a breach. But there should be; it is an efficient breach. Richard A. Posner, ECONOMic ANAlysis of LAw 120 (6th ed. 2003).

113. See, e.g., Charlotte K. Goldberg, Emotional Distress Damages and Breach of Contract: A New 
A fuller discussion of the scholarly debate over whether allowing tort damages for breach of contract claims really "upsets" efficient breach is beyond the scope of this Article. However, the relevant insight derived from this debate is that breaches of contracts may in fact impact contracting parties in meaningful but non-monetary ways. That is, breaches of contract may cause emotional distress to aggrieved parties, they may affect how parties view themselves and their counter-parties as part of larger commercial, social, and/or political communities, and they may impact the culture of particular contracting communities. ${ }^{114}$ Put another way, breaches of contractparticularly those that are based on breaches of the duty of good faith - may have public as well as private effects. And, if that is the case, why should common law contract doctrine, as a matter of theory, exclude the contemplation of public law norms?

\section{B. Legal Realism and the Break-down of the Public/Private Distinction}

Scholars and commentators have been interrogating and challenging the purportedly sharp categorical divide between public and private law since, at the latest, the early $1900 \mathrm{~s}$. In effecting their critiques of the public/private distinction in the 1920s and 1930s, legal realists like Robert Hale and Morris Cohen paid particular attention to property and contract law, which then (as now) represented the classically entrenched conception of private law. ${ }^{115}$

Approach, 20 U.C. Davis L. Rev. 57 (1986) (indicating that tort damages should be available in breach of contract cases where contract involves emotional subjects, but not when contract is purely commercial and profit-making); Amy H. Kastely, Compensation for Lost Aesthetic and Emotional Enjoyment: A Reconsideration of Contract Damages for Nonpecuniary Loss, 8 U. HAw. L. REv. 1 (1986)(advancing the argument that contractual expectation damages encompass recovery for emotional distress); John A. Sebert, Jr., Punitive and Nonpecuniary Damages in Actions Based upon Contract: Toward Achieving the Objective of Full Compensation, 33 UCLA L. REv. 1565 (1986) (arguing that economic analysis demonstrates that denying emotional distress damages in breach of contract actions is unsound because it allows a breaching party to avoid the full costs of his breach, thus producing "inefficient breach"); Douglas J. Whaley, Paying for the Agony: The Recovery of Emotional Distress Damages in Contract Actions, 26 SufFolK U. L. REV. 935 (1992) (advocating that special rules limiting recovery of damages for emotional distress in breach of contract actions should be dropped in favor of general requirements of foreseeability and proof with reasonable certainty).

114. Professor Robin Paul Malloy has developed a semiotic model of market analysis that emphasizes market incentives and disincentives focusing on the politics, community, and culture of market actors, rather than the maximization of (a Kaldor-Hicks model of) efficiency. See Robin PaUl Malloy, Law And Market Economy: Reinterpreting the Values of LaW And Economics (2000).

115. See generally Morris R. Cohen, The Basis of Contract, 46 HARV. L. Rev. 553 (1933); Robert L. Hale, Coercion and Distribution in a Supposedly Non-Coercive State, 38 Pol. SCI. Q. 470 (1923). 
In his seminal The Basis of Contract, Professor Cohen took on the classical roots of contractualism, which he described as:

the view that in an ideally desirable system of law all obligation would arise only out of the will of the individual contracting freely, [which view in turn] rests not only on the will theory of contract but also on the political doctrine that all restraint is evil and that the government is best which governs least. ${ }^{116}$

Cohen's critiques of will theory and contractualism are replete with ideas that now proliferate the contemporary work of critical and non-critical scholars, and in particular, of those who continue to challenge the now all-pervasive conventional economic analysis of law. ${ }^{117}$ Cohen wrote:

It was natural for the representatives of the growing commercial and industrial interests to view the state, controlled as it had been by landed barons and prelates . . . , as exclusively an instrument of oppression, and necessarily evil. But their argument overshot its mark. They forgot that not only industry but also the whole life of civilization depends on the feeling of security that the protection of the government or organized community affords.

The philosophy of freedom or liberty illustrates one of the most pervasive and persistent vices of reasoning on practical affairs, to wit, the setting up of premises that are too wide for our purpose and indefensible on their own account. ${ }^{118}$

Cohen went on to criticize a broad range of liberal philosophical defenses to contractualism and exposed and exalted the essential public function of contract law: "to standardize conduct by penalizing departures from the legal norm," both through the awarding of damages or specific performance, as well as through the declaration of certain contracts as void or voidable. ${ }^{19}$

In 1923, Robert Hale in his famous Coercion and Distribution in a Supposedly Non-Coercive State more specifically began to deconstruct the public/private distinction by revealing the ways in which legal and philosophical discourse had, up to then, obscured the private aspects of

116. Cohen, supra note 115, at 558 (emphasis added).

117. See, e.g., Malloy, supra note 114; Ian Ayres, Never Confuse Efficiency with a Liver Complaint, 1997 WIS. L. REv. 503, 504-06 (1997) (describing the "hegemony of economic analysis" in law); Gillian K. Hadfield, An Expressive Theory of Contract: From Feminist Dilemmas to a Reconceptualization of Rational Choice in Contract Law, 146 U. PA. L. REv. 1235 (1998) (applying reconception of "rational choice" theory to effect a feminist economic analysis of contract law); Duncan Kennedy, Form and Substance in Private Law Adjudication, 89 Harv. L. Rev. 1685, 1740-53, 1762-66, 1776 (1976) (arguing that economic principles embedded in legal rules and standards are "instrumental to the pursuit of substantive objectives").

118. Cohen, supra note 115, at 559 (emphasis added).

119. Id. at 589 
coercion, while simultaneously vilifying its public aspects. ${ }^{120}$ To Hale, threats and promises, whether public in the form of state regulation, or private in the form of negotiated (or un-negotiated) contracts, were both coercive in an amoral sense because both function to influence a person's conduct in positive and negative ways. ${ }^{121}$ To Hale, what made the difference was power. Hale's analysis of wealth distribution focused not on the coercive nature of public regulation and private exchange transactions, but on whether power was concentrated in the hands of private or public actors. Hale wrote:

If [the] distinctions [between immorally coercive threats and moral promises] are all invalid, then, ... . it seems to follow that the income of each person in the community depends on the relative strength of his power of coercion, offensive and defensive. . . . This power is frequently highly centralized, with the result that the worker is frequently deprived, during working hours and even beyond, of all choice over his own activities.

To take this control by law from the owner of the plant and to vest it in public officials or in a guild or in a union organization elected by the workers would neither add to nor subtract from the constraint which is exercised with the aid of the government. It would merely transfer the constraining power to a different set of persons. It might result in greater or in less actual power of free initiative all around, but this sort of freedom is not to be confused with the "freedom" which means absence of governmental constraint. ${ }^{122}$

Hale's articulation of the distinction between "power of free initiative all around" and the neo-liberal conception of freedom is striking in that it prefigured theories of the circulative nature of power, which are so foundational to cultural studies. ${ }^{123}$ Moreover, such theories of how power circulates give rise to a question that underlies, in part, this portion of the Article: to the extent that American jurisprudence maintains the distinction between public and private law, how does line-drawing by courts, commentators, and scholars between the public and the private domains impact distributions of power and, consequently, economic and sociopolitical equality?

120. Hale, supra note 115 , at $471-78$.

121. Id. at $471-79$.

122. Id. at 477-78 (emphasis added).

123. See Stuart Hall, The Work of Representation, in Representation: Cultural REPRESENTATIONS AND Signif Ying Practices 41-51 (Stuart Halled., 1997) (discussing circulative nature of discourse and its relationship to knowledge, truth, and power in society). 
The triumphs of the legal realism movement were many, ${ }^{124}$ but the continued entrenchment of the distinction between public and private law remains as one of the movement's greatest failures. Claiming, for example, as Professor Clare Dalton has that "the Realist challenge to the 'privateness' of contract has been assimilated and defused," 125 feminist, critical, and liberal scholars, among others, attempted to make concentrated interventions to resuscitate the debate over the public/private distinction in the early to mid1980s. ${ }^{126}$ Notably, in 1985, Professor Dalton challenged the "privateness of contract" in her controversial An Essay in the Reconstruction of Contract Doctrine. ${ }^{127}$ There, she asserted that "all contracts are public." 128 She supported this claim by re-analyzing quasi-contract, or implied-in-law contract, alongside implied in-fact-contract, pointing out that both functioned to impose "social norms" on individual parties in order "to create a public obligation." "29 Dalton also re-examined the doctrines of unconscionability, duress, the parol evidence rule, consideration, and reliance. ${ }^{130}$ In all of these contexts, she, like Professor Duncan Kennedy, ${ }^{131}$ deconstructed the modern notion of "objectivity" - of the purported difference between form and substance - in the law. ${ }^{132}$ Moreover, Dalton made central to her inquiry the questions of knowledge and power. She asked explicitly:

124. Legal realism's most significant triumph was the adoption of the Uniform Commercial Code by every state in the country, except Louisiana. David V. Snyder, Private Lawmaking, 64 Oніо ST. L.J. 371,379 (2003). Its chief architect, Karl Llewellyn, was among the most important and well-known of the Realists. He argued that commercial law developed into its modern, stabilized state not because it embodied and formalistically enacted a set of legal rules, but because particularized social and economic circumstances compelled the judicial creation of a body of law that developed into a coherent doctrine. See Note, 'Round and 'Round the Bramble Bush: From Legal Realism to Critical Legal Scholarship, 95 Harv. L. Rev. 1669, 1671-73 (1982) (discussing Karl Llewellyn, On Warranty of Quality, and Society, 36 Colum. L. Rev. 699 (1936), and Karl Llewellyn, On Warranty of Quality, and Society: II, 37 Colum. L. ReV. 341 (1937)).

125. Dalton, supra note 3, at 1014.

126. See, e.g., Mary Ann Glendon, The Transformation of American Landlord-Tenant Law, 23 B.C. L. REV. 503 (1982) (tracing the development of landlord-tenant law from its historical roots in private law of contract, to its publicly regulated form); Symposium, The Public/PrivateDistinction, 130 U. PA. L. Rev. 1289 (1982) (discussing this symposium on the public/private distinction in law, featuring papers on topics such as the history of the distinction, state action and liberal theory, and distinction in the contexts of labor law and corporate law).

127. Dalton, supra note 3.

128. Id. at 1001 .

129. Id.

130. Id. at 1024-95.

131. See generally Kennedy, supra note 117.

132. Dalton, supra note 3, at 1042-54. 
Why do we allow our decisionmakers to conduct their search for answers to concrete human problems in this particular form [that is, in the form dictated by particular legal rules relating to the subjects mentioned above]? . . In the name of understanding of the human condition do our judges exert authority over us in our interactions with others? In the name of what understanding of the human condition do we allow ourselves to be thus constrained in imagining the possibilities of relationship with others? ${ }^{133}$

Thus, as exemplified by the work of Dalton, Kennedy, Hale, and Cohen, most of the scholarship interrogating the public/private distinction has focused on dismantling the mythic categories of public and private law.

Additionally, in recent years, some scholars interested in the public/private distinction have begun to re-direct their theoretical and doctrinal inquiries. ${ }^{134}$ The focal shift being effected by these scholars is an extraordinarily important one, given the global proliferation of American-style capitalism and the political and economic trend toward privatization of institutions and systems historically regarded as essentially public (such as prisons, primary education, etc.). Along these lines, Professor Jody Freeman has advocated the extension of public law norms through privatization. She writes:

\footnotetext{
Instead of seeing privatization as a means of shrinking government, I imagine it as a mechanism for expanding government's reach into realms traditionally thought private. In other words, privatization can be a means of "publicization," through which private actors increasingly commit themselves to traditionally public goals as the price of access to lucrative opportunities to deliver goods and services that might otherwise be provided directly by the state. So, rather than compromising democratic norms of accountability, due process, equality, and rationality - as some critics of privatization fear it will-privatization might extend these norms to private actors through vehicles such as budgeting, regulation, and contract. ${ }^{135}$
}

Freeman's work focuses on why and how the government should require adherence to public law norms as part of the consideration for its contracts and, as such, on the "relationship between administrative law and the role private actors play in public governance." 136 Freeman further frames her analysis as one incorporating what she calls "the public law perspective," which is concerned not primarily with "whether privatization is efficient, but

133. Id. at 1003 .

134. See, e.g., Jody Freeman, Extending Public Law Norms Through Privatization, 116 Harv. L. Rev. 1285 (2003) (discussed infra pp. 28-29); Snyder, supra note 124, at 371 (arguing that because a significant amount of law is privately made, such law should be subjected to the same kinds of questioning as publicly made law).

135. Freeman, supra note 134, at 1285.

136. Id. at 1288 . 
whether it erodes the public law norms that ... constitutional and statutory limits are designed to protect." 137

This Article merges the approaches of the legal realists and their critical descendants with those of more pragmatic scholars, like Freeman, who are attempting to re-order internally the goals of privatization. This attempt at such merger is not nearly so radical as it might sound, for entire sub-categories of contract law, such as in the insurance, consumer, labor, and landlord/tenant contexts, are regulated quite heavily by federal and state legislatures. This Article merely seeks to effect the "publicization" of the private law of contract vis-à-vis the application of the good faith doctrine, with the specific and explicit goal of eliminating racial and gender subordination. Doctrinally, the implied obligation of good faith is the ideal vehicle for such publicization, given its murky definitional contours and, as I have argued elsewhere, given its currently hollow doctrinal state. ${ }^{138}$ Theoretically, it makes sense to use the implied obligation of good faith to these ends, because implied contractual obligations arise for the very purpose of effecting and prescribing certain cultural and social norms between contracting parties, which norms are transmitted and enforced by the courts as both a descriptive and normative matter. In that sense, implied obligations are in their very nature public obligations, and, if that is so, then they should incorporate public law norms. Thus, in borrowing from the classic legal realist controversy over the publicprivate distinction to incorporate a public law norm of equality, defined critically into contract law, this Article advocates a form of critical race theory that it calls critical race realism.

\section{The Inadequacies of Section 1981 of the Civil Rights ACT OF 1866}

In enacting sections 1981 and 1982 of the Civil Rights Act of 1866, Congress expressed its commitment to equality in contracting, not only as between an individual and the state but also as between private individuals. This historical commitment to racial equality in public and private contracting provides some precedent for my proposed good faith discrimination claim, but would such a claim simply duplicate the remedies offered by section 1981 ? This Part argues that because section 1981 offers only very limited remedies to those harmed by inequality in contracting, the good faith discrimination

137. Id. at 1302 .

138. See Houh, supra note 1. 
claim not only would not be duplicative of the section 1981 claim, but also would go far to address the forms of domination and oppression discussed in Part I of this Article.

\section{A. A Primer on Section 1981}

Section 1981 of the Civil Rights Act of 1866 provides in relevant part that: "All persons within the jurisdiction of the United States shall have the same right in every State and Territory to make and enforce contracts . . . as is enjoyed by white citizens." ${ }^{\prime 39}$ In 1991, Congress amended section 1981 to overrule Patterson v. McLean Credit Union, a Supreme Court case that restricted then-section 1981 's applicability to discrimination arising only from the formation of the original contract. ${ }^{140}$ The 1991 amendments substantially broadened section 1981's post-Patterson scope by adding to it subsections (b) and (c), which, according to the amendments' legislative history, collectively overrule Patterson in its entirety. ${ }^{141}$ Specifically, subsection (b) defines "make and enforce contracts" to include "the making, performance, modification, and termination of contracts" and subsection (c) provides that "[t]he rights protected by this section are protected against impairment by nongovernmental discrimination and impairment under color of State law." ${ }^{142}$

139. 42 U.S.C. $\S 1981(2000)$.

140. Patterson v. McLean Credit Union, 491 U.S. 164 (1989). In Patterson, the plaintiff, Brenda Patterson, a black woman, brought a claim against her former employer under section 1981, alleging harassment, failure to promote, and termination based on her race. Id. at 169 . Her claim failed at every level, and the Supreme Court, in a five-four decision, held that the language, "to . . enforce contracts," was to be interpreted narrowly. Id. at 180-81. Justice Kennedy, writing for the majority, stated that "the right to make contracts does not extend, as a matter of either logic or semantics, to conduct by the employer after the contract relation has been established, including breach of the terms of the contract or imposition of discriminatory working conditions." Id. at 177. To be extra clear about section 1981's narrow scope as a civil rights statute, he further stated that section 1981 is not to be employed or read as "a general proscription of racial discrimination." Id. at 181. As such, the Court held that racial harassment is not actionable under section 1981. Id. at 182. However, the Court did leave open the possibility that Ms. Patterson's section 1981 claim for failure to promote was actionable, leaving to the lower court the question of whether the expectations under the new position were sufficiently different in nature so as to justify a "new and distinct relation" between Patterson and her former employer and, thus, the formation of a new contract between them. Id. at 185 .

141. According to the legislative history, one purpose of the Act was "to respond to recent decisions of the Supreme Court by expanding the scope of relevant civil rights statutes in order to provide adequate protection to victims of discrimination.” Civil Rights Act of 1866 Amendments, Pub. L. No. 102-166, $\S 3(4), 1991$ Stat. 1745 (1991).

142. 42 U.S.C. § 1981(b), (c) (2000). 
Since the mid-1970s, when the Supreme Court held that section 1981 applies to the making and enforcement of private as well as public contracts, ${ }^{143}$ section 1981 has been used most extensively as an alternative to, or in conjunction with, Title VII ${ }^{144}$ in employment discrimination cases. By its terms, however, section 1981, unlike Title VII, is limited to racial discrimination. ${ }^{145}$ Historically, though, section 1981 has offered some procedural and remedial advantages over Title VII. For example, under section 1981, a plaintiff may sue any employer, not just one with fifteen or more employees, as required under Title VII. ${ }^{146}$ Also, an employee may bring suit against an employer without having exhausted her administrative remedies by first filing a complaint with the Equal Employment Opportunity Commission, as she is required to do under Title VII. ${ }^{147}$ Additionally, the statute of limitations for a 1981 claim, which is usually borrowed from an applicable state statute or, if the claim was made possible after 1990, is four years, ${ }^{148}$ which runs longer than the 180 or 300 day EEOC filing requirement under Title VII. ${ }^{149}$ Under section 1981, plaintiffs also can request jury trials, whereas, under Title VII, they historically could not. In terms of remedies, plaintiffs also preferred remedies that have always been available under section 1981 but were not historically available under Title VII, such as the recovery of compensatory and punitive damages. ${ }^{150}$ However, in 1991, Congress amended Title VII, permitting plaintiffs not only to request jury trials, but also to recover compensatory and punitive damages in cases where the plaintiff could not recover under section $1981 .^{151}$

143. Runyon v. McCrary, 427 U.S. 160 (1976).

144. 42 U.S.C. $\$ 2000 \mathrm{e}-2000 \mathrm{e}-17$ (2000).

145. 42 U.S.C. $\S 1981$ (a) (2000). Title VII prohibits discrimination based on race, color, religion, sex, or national origin. 42 U.S.C. $\S 2000 \mathrm{e}-2$ (2000).

146. 42 U.S.C. $\$ 2000 \mathrm{e}(\mathrm{b})(2000)$ (defining “employer" as "a person engaged in an industry affecting commerce who has fifteen or more employees").

147. 42 U.S.C. $\S 2000 \mathrm{e}-4(2000)$.

148. See Goodman v. Lukens SteelCo., 482 U.S. 656, 660 (1987) (holding that federal courts should select "the most appropriate or analogous state statute of limitations" for § 1981 claims); but see Jones v. R.R. Donnelley \& Sons Co., 124 S. Ct. 1836, 1845 (2004) (holding that the $§ 1981$ claim is governed by a federal "catch-all" four-year statute of limitations if claim was made possible by post-1990 enactment of such statute).

149. 42 U.S.C. $\$ 2000 \mathrm{e}-5$ (e)(1) (2000) (explaining that adverse actions occurring more than 300 days before the filing of an EEOC complaint are time-barred).

150. Prior to the passage of the 1991 amendment to the Civil Rights Act, 42 U.S.C. § 1981a(c) (2000), a plaintiff alleging a violation of Title VII could recover only back pay and front pay. Because back pay and front pay have historically been recognized as equitable relief under Title VII, neither party was entitled to a jury trial; Title VII claims were tried to the bench. Lehman v. Nakshian, 453 U.S. 156 (1981).

151. See 42 U.S.C. $\S 1981 a(c), a(a)(1)(2000)$. 
Despite the differences between section 1981 and Title VII, the same critiques apply to both, as section 1981 case law has incorporated the McDonnell-Douglas burden-shifting framework imposed upon plaintiffs who bring disparate treatment or intentional discrimination claims under Title VII. ${ }^{152}$ This is especially so because unlike under Title VII, a plaintiff asserting a violation of section 1981 may not bring a disparate impact claim based on racially neutral policies that have a disparate racial impact; rather, a section 1981 plaintiff may only assert a claim of intentional or purposeful discrimination. ${ }^{153}$ Thus, in order to assert a section 1981 claim, a plaintiff must show that: (1) she is a member of a racial minority group; (2) the defendant had an intent to discriminate; and (3) the discrimination concerned one or more of the activities enumerated in the text of section 1981 (that is, according to section 1981(b), "the making, performance, modification, and termination of contracts and the enjoyment of all benefits, privileges, terms, and conditions of the contractual relationship"). ${ }^{154}$ Moreover, because the McDonnell-Douglas burden-shifting framework applies to section 1981 claims, ${ }^{155}$ once a plaintiff has established her prima facie case, the burden shifts to the defendant to rebut that claim simply by producing some legally sufficient evidence of a legitimate, nondiscriminatory reason for the adverse treatment. ${ }^{156}$ If the employer meets this burden of production, then the plaintiff must show by a preponderance of evidence that the legitimate reasons offered by the defendant were not its true reasons for the adverse treatment, but mere pretext. ${ }^{157}$ Moreover, in order for a plaintiff to prevail on her pretext argument, she must show not only that the proferred reason is false, but that the discrimination is the "real" reason. ${ }^{158}$

152. See Patterson v. McLean Credit Union, 491 U.S. 164, 186 (1989), superceded in part by The Civil Rights Act of 1991, 42 U.S.C. $§ 1981$ a(c) (2000) (explaining that the McDonnell-Douglas scheme of proof is applicable to $\$ 1981$ claims); McDonnell Douglas Corp. v. Green, 411 U.S. 792, 802-05 (1973).

153. See Gen. Bldg. Contractors Ass'n v. Pennsylvania, 458 U.S. 375, 391 (1982) (holding that $\S 1981$, like the Equal Protection Clause of the Fourteenth Amendment, "can be violated only by purposeful discrimination"); see also Mitchell v. DCX, Inc., 274 F. Supp. 2d 33, 44-45 (D.D.C. 2003) (holding that the disparate impact theory of discrimination is not available to plaintiff asserting violation of $\S 1981$ ).

154. 42 U.S.C. § 1981(b) (2000); see also O’Neill v. Gourmet Sys. of Minn., Inc., 213 F. Supp. 2d 1012, 1016 (W.D. Wis. 2002).

155. Patterson, 491 U.S. at 186.

156. See Tex. Dep't of Cmty. Affairs v. Burdine, 450 U.S. 248, 254-56 (1981).

157. See id. at 255-56; McDonnell-Douglas, 411 U.S. at 804-05.

158. See Evans v. Toys R Us-Ohio, Inc., 32 F. Supp. 2d 974, 985 (S.D. Ohio 1999) (“[A] reason cannot be proved to be a 'pretext for discrimination' unless it is shown both that the reason was false, and that discrimination was the real reason.”) (quoting St. Mary's Honor Ctr. v. Hicks, 509 U.S. 502, 512 n.4). 


\section{B. Critiques of Intentionality}

Critiques of antidiscrimination law's obsession with intentionality abound in critical race scholarship. ${ }^{159}$ Professor Angela Harris has perhaps best summarized the critique of the intentionalist model of discrimination, which reifies racial subordination by "mediat[ing] the tension between egalitarian ideals and status quo preservation":

The essentially moralistic discourse of discrimination condemns the racialist ideologies that pervaded most of twentieth century law and public policy, but it has also placed a premium on proving individual intent to harm and distinguishing innocent victims from evil victimizers. . . . [T] his model of discrimination . . . works to identify intentional wrongdoers and demonstrable victims, but leaves untouched unconscious racism, everyday cognitive bias, and institutional structures that faithfully perpetuate patterns of racial subordination. As the legal structures that continue to disadvantage people of color become increasingly "race-neutral" in a constitutional sense, the moral model of discrimination facilitates both the denunciation of bigotry and the maintenance of existing distributions of wealth and power. ${ }^{160}$

This intentionalist model of discrimination, which itself derives from an individualist and neo-liberal model of equality, is associated in contemporary scholarship and commentary with the "racial realism" movement. ${ }^{161}$ In general, racial realists advocate for the continued use of the colorblind approach to law-and policy-making, an approach Neil Gotanda has rigorously critiqued. ${ }^{162}$ Further, racial realists base their arguments on three assumptions about racial equality in the United States. First, racial realists claim that "racism is a thing of the past." They vilify liberals as deniers of this truism who attempt to paint a false picture of America and white Americans as "irredeemably racist." 163 To racial realists, affirmative action policies exemplify this liberal agenda of denial and the liberal "fixation on color."164 Second, racial realists claim that material inequalities, taking the form of racial disparities in, for example, employment, housing, political representation, and income, cannot be explained by white racism,

159. See, e.g., Freeman, supra note 39 (asserting that constitutional antidiscrimination jurisprudence legitimizes racial discrimination because it developed from a perpetrator, as opposed to victim, perspective); Lawrence, supra note 39 (critiquing the Washington $v$. Davis decision and its intentionality requirement for constitutional equal protection claims).

160. Harris, supra note 39, at 2003.

161. Michael K. Brown et al., White-Washing Race: The Myth of a Color-Blind Society 5-9, passim (2003).

162. See supra Part I.B.2.

163. BROWN ET AL., supra note 161, at 6 .

164. Id. (quoting Jim SleEPer, Liberal Racism 9, $77-78$ (Penguin Books 1997)). 
notwithstanding the existence of small numbers of white supremacists who occupy the ideological extreme. Rather, these racial inequalities are explained by black moral and cultural pathology and failure. ${ }^{165}$ Finally, racial realists argue that to the extent racial inequality still exists, it is due not to entrenched institutional and cultural white supremacy, but to the failures of civil rights leaders who care little about their constituents and only about their own power, which they amass by racially "balkanizing" political, social, and educational life. ${ }^{166}$

Although one could critique at some length — and many have ${ }^{167}$ - the racial realists' assertions, one of racial realism's deepest flaws, both analytically and methodologically speaking, is found in its decontextualized and stunningly unsophisticated framing - or, more accurately, erasing — of the ongoing racial "problem." Although racial realists demonstrate knowledge of the histories of American civil rights movements, they process that knowledge in an overly linear and discrete fashion: movements happen, laws are passed, and "problems" like racism are solved. But racial realists fail to understand how "the past has shaped the future"168 and do not acknowledge the undeniable and inextricable links between existing material inequalities and entrenched ideological legacies. They are oblivious to the existence of Young's "five faces of oppression," ${ }^{69}$ let alone to how those faces work together to reproduce the conditions of inequality.

Moreover, because of its ideological commitment to the neo-liberal conception of individualism and, thus, formal equality, racial realism attributes existing racial inequalities to the moral and cultural weaknesses of particular communities of color on the one hand, and the moral and cultural strengths of the majority community - and problematically of other "model minority" communities ${ }^{170}$ - on the other. These explanations, however,

165. Id. at 6-7.

166. Id. at 7; Dinesh D'Souza, The End of Racism: Principles for a Multiracial Society ch. 6 (1995) (citing Stephen Thernstrom \& Abigail Thernstrom, America in Black and White: One NATION, InDivisible 299-300 (1997)).

167. In fact, several scholars from various fields-including political science, sociology, law, education, and criminology - recently co-authored an excellent book that specifically responds to and deconstructs - substantively and methodologically - the claims of the racial realists. See Brown et AL., supra note 161.

168. Id. at 21.

169. See supra Part I.A.

170. In this regard, Claire Jean Kim has written on the "racial triangulation" of Asian Americans, in an attempt to move race discourse beyond the black-white paradigm. Kim writes:

Racial triangulation occurs by means of two types of simultaneous, linked processes: (1) processes of "relative valorization," whereby dominant group A (whites) valorizes subordinate group B (Asian 
closely resemble more blatant articulations of the innate superiority of the white race over all others and echo Justice Harlan's famous dissent in Plessy v. Ferguson where, although holding fast against the separate-but-equal doctrine and stating that "[o]ur Constitution is colorblind," he also opined that:

[t]he white race deems itself to be the dominant race in this country. And so it is, in prestige, in achievements, in education, in wealth and in power. So, I doubt not, it will continue to be for all time, if it remains true to its great heritage and holds fast to the principles of constitutional liberty. ${ }^{171}$

While Justice Harlan is lauded more often than not in constitutional law classes as a great champion of racial equality, a careful reading of his dissent reveals a challenge to black- and brown-skinned peoples to rise to the level of the white race, a challenge that is brimming with Harlan's confidence in their inherent inability to do so. It appears, in this post-civil rights era, that racial realists are determined to prove Justice Harlan right.

This Article uses critical race realism to respond to those efforts through its proposal of the good faith discrimination claim. Critical race realism has, primarily, three analytical goals. First, it aims to address in its analytical scope, each of Young's five faces of oppression, individually and collectively. Second, it shifts the focus of discrimination analysis away from the intent of the perpetrator, and brings to the center of this analysis the material and ideological conditions of the "victim class." 172 Finally, as part of its analytical methodology, critical race realism seeks to deconstruct explicitly the public/private distinction where that distinction masks and enables conditions of subordination.

Americans) relative to subordinate group C (blacks) on cultural and racial grounds in order to dominate both groups, but especially the latter, and (2) processes of "civic ostracism," whereby dominant group A (whites) constructs subordinate group B (Asian Americans) as immutably foreign and unassimilable with whites on cultural and racial grounds in order to ostracize them from the body politic and civic membership ....

Claire Jean Kim, The Racial Triangulation of Asian Americans, in Asian Americans and Politics: Perspectives, Experiences, Prospects 39, 41 (Gordon H. Chang ed., 2001). See also Sumi K. Cho, Converging Stereotypes in Racialized Sexual Harassment: Where the Model Minority Meets Suzie Wong, 1 J. GENDER RACE \& Just. 177, 185-90 (1997)(discussing how "[t] he model minority myth was developed in the mid-1960s to provide a counter example to politically active African Americans"); Natsu Taylor Saito, Alien and Non-Alien Alike: Citizenship, "Foreignness," and Racial Hierarchy in American Law, 76 OR. L. REv. 261 (1997) (discussing and analyzing the legal "racing" of Asian Americans as both model minorities and permanently foreign).

171. Plessy v. Ferguson, 163 U.S. 537, 559 (Harlan, J., dissenting) (emphasis added).

172. Freeman, supra note 39, at 1053. 


\section{A Good Faith Claim for Discrimination (Re-Theorized)}

\section{A. The Good Faith Discrimination Claim}

This Article's proposed common law claim for discrimination is doctrinally rooted not in civil rights law, but in contractual good faith law. I have already laid the theoretical groundwork for this doctrinal shift in Parts I and II of this Article and in Critical Interventions, but more practically speaking, what is to be gained by employing a common law discrimination claim rooted in good faith over a traditional civil rights claim? First, on a concrete doctrinal level, the fashioning of the elements of such a claim would eliminate the almost insurmountable procedural hurdles imposed by the McDonnell-Douglas burden-shifting framework, and which has enshrined in civil rights doctrine the perpetrator perspective and intentionality. ${ }^{173}$

Second, the availability of such a claim would have profound expressive and educative value. In transferring the lessons of critical race and feminist legal theory to plaintiffs, defendants, their lawyers, judges, and jurors through the elements of the claim, the law might not only alter the rhetoric of discrimination and colorblindness that now dominates civil rights law; it might also impact popular cultural understanding of how racial subordination exists and persists as a historical and socially contextualized phenomenon. On a more general level, making available such a non-statutory, non-civil rights claim would express a radically different and more profound commitment to racial (and gender and sex) equality (as defined supra), for fashioning the claim as a breach of good faith claim would place the equality principle, which currently plays a lesser role in contract law, for example in the doctrines of unconscionability, undue influence, duress, incapacity, and misrepresentation, on the same level, for example, as the principle of free and individual will in contracting, a value prioritized in both classical and modern contract law. ${ }^{174}$ Thus, the good faith discrimination claim would allow two

173. See supra Parts III.A and I.B.1.

174. Classical contract law prioritizes individual free will and freedom of contract. In order to protect and develop that value, it developed myriad and rigid rules and sub-doctrines-such as the duty to read - which obviously favored at the very least, literate parties who could read (sophisticated parties) over those who could not read (unsophisticated parties). See, e.g., Ray v. William G. Eurice \& Bros., 93 A.2d 272, 278 (Md. 1952) (holding in part that, absent fraud or duress, "one having the capacity to understand a written document who reads and signs it, or, without reading it or having it read to him, signs it, is bound by his signature in law"). Significantly, one of the leading contracts casebooks uses the Eurice \& Bros. case to represent the classical, "objective" theory of intent in contract law. See Charles L. Knapp et al., 
purportedly competing values, freedom to contract (or not to contract) and equality, to co-exist. ${ }^{175}$

Some might believe that this Article's attempt to incorporate equality principles into areas such as contract law is deeply misguided. However, in addition to the Congressional enactment of section 1981, analogies in contract law exist to support the creation of a good faith discrimination claim that protects parties who are subject to discrimination in contracting. For example, the UCC in some part and consumer protection statutes in whole part developed to respond to what was viewed as the common law's preference for sellers over buyers, where buyers are presumed to be the "weaker" party in many commercial transactions and practically all consumer transactions. Surely, if we have been, and are so, willing to provide protection in the contractual context to presumptively disfavored categories of parties such as buyers and/or consumers, we should be able to do so with respect to categories of parties who have been disfavored in the contractual context because of their race, gender, and/or sex.

Moreover, as discussed supra, this Article posits that although legal categorical distinctions are important in many respects, to the extent the blurring of that distinction may serve to effect racial, gender, and/or sex equality, theoretical and doctrinal interventions that deconstruct the publicprivate distinction must occur. For purposes of this Article, the next questions are practical ones: Should the common law claim for discrimination manifest as a claim for contractual or tortious breach of good faith? And, in order to address the more theoretical issues raised in this Article, what should the elements of the claim look like?

Problems in Contract Law: Cases and Materials 27-36 (5th ed. 2003). A more contemporary example is the scholarly and juridical protection of efficient breach, which occurs when:

in some cases a party ... break [s] his contract simply because his profit from breach would exceed his profit from completion of the contract. If it would also exceed the expected profit to the other party from completion of the contract, and if damages are limited to the loss of that profit, there will be an incentive to commit a breach. But there should be; it is an efficient breach. Richard A. Posner, ECONOMic ANALysis of LAW 120 (6th ed. 2003).

175. Further, the claim could also address an important observation made by critical scholars, that American constitutional jurisprudence tends to prioritize certain individualist rights and values, such as the right to free speech, over, for example, racial equality. See, e.g., Charles R. Lawrence III, If He Hollers Let Him Go: Regulating Racist Speech on Campus, 1990 Duke L.J. 431, 467 (arguing that equality should be a precondition of free speech and where free speech rights and equality clash, more weight should be placed on "that side of the balance aimed at the removal of the badges and incidents of slavery that continue to flourish in our culture"). 


\section{Contractual or Tortious Breach of Good Faith-A Brief Comment on Remedies}

Whether the good faith discrimination claim should take the form of a breach of contract or tort claim in part depends on the theory of the desired remedy, that is, whether the remedy should be compensatory and forwardlooking as a matter of contract, or punitive as a matter of tort. As a remedial matter, this Article argues that the proposed claim should be contractual in nature. ${ }^{176}$ First, the new claim should be contractual because the tort claim for discrimination already exists in the form of the civil rights claim. The civil rights claim may be considered a species of tort in that it seeks a punitive remedy for victims of discrimination, as defined by the current antidiscrimination discourse, based on harms incurred due to the breaching of a publicly circulating moral code and/or ethical standard against identitybased forms of discrimination. Second, theorizing the good faith discrimination claim as contractual rather than tortious in nature is most consistent with an overarching goal of this Article, to reframe and reinterpret the current and dominant economically-driven values of contract jurisprudence, ${ }^{177}$ whose purported neutrality has been critiqued at length in the scholarship. ${ }^{178}$

Third, and most importantly, this Article cautions against the development of the tortious good faith discrimination claim because the availability of punitive damages for both torts and civil rights violations - which plays a role in framing how we have up to now thought about what constitutes illegal discrimination-will enable courts to more easily import the existing civil rights fixation on perpetrator perspective and intentionality, discussed supra, into the common law cause of action. This Article prefers a remedy that aims not to punish the evil wrongdoer, but rather

176. A fuller discussion of the theories of contract and tort remedy, while enormously important, is beyond the scope of this Article, particularly as I believe contract remedies should also be re-theorized. I leave that discussion to another paper.

177. See Critical Interventions, supra note 2, at 1038-49 (arguing that despite the contrasting goals - efficiency and fairness/justice - of the two dominant models of good faith, both work to effect efficiency).

178. See, e.g., Dalton, supra note 3 and text accompanying notes 124, 126-32; Jay M. Feinman, Critical Approaches to Contract Law, 30 UCLA L. REv. 829, 830 (1983) (exploring the role of contract law as "a market facilitator and as a legitimation device" in law more generally); Kennedy, supra note 117; Patricia A. Tidwell \& Peter Linzer, The Flesh-Colored Band Aid-Contracts, Feminism, Dialogue, and Norms, 28 Hous. L. REv. 791 (1991) (examining effect of different cultural norms, including feminist norms, on concepts of objectivity and neutrality in contract law). 
to compensate the non-breaching party for the extra work imposed upon her as a result, for example, of her employer's racially-rooted, and, consequently, unreasonable expectations under the employment contract. ${ }^{179}$

\section{The Elements of the Claim ${ }^{180}$}

It would be helpful, at this point, to define or set forth briefly, the modern definition of contractual good faith. Unfortunately, because good faith jurisprudence remains in a somewhat unsettled state, ${ }^{181}$ the task is a somewhat difficult one. Very generally speaking, the implied obligation of good faith requires that neither of the contracting parties perform in a such way that would deprive her counter-party of her reasonable expectations under the contract. ${ }^{182}$ The good faith discrimination claim proposed in this Article

179. Many courts acknowledge the general rule that at-will employment is terminable upon notice for any or no reason, but recognize exceptions to that rule, including an implied obligation of good faith and fair dealing exception. See, e.g., Wagenseller v. Scottsdale Mem'l Hosp., 710 P.2d 1025, 1030-33, 1036-40 (Ariz. 1985), superceded by ARiz. Rev. Stat. § 23-1501 (2002); E.I. DuPont de Nemours \& Co. v. Pressman, 679 A.2d 436, 437-38 (Del. 1996). But see, e.g., Dandridge v. Chromcraft Corp., 914 F. Supp. 1396, 1406-07 (N.D. Miss. 1996) (noting that Mississippi law does not recognize an implied obligation of good faith and fair dealing in at-will employment agreements); Rios v. Tex. Commerce Bancshares, Inc., 930 S.W.2d 809, 816 (Tex. App. 1996) (noting that "neither the [Texas] legislature nor the supreme court [of Texas] has recognized an implied covenant of good faith and fair dealing in employment relationships").

180. This subpart excludes a discussion of the element of damages, in part because damages have been briefly addressed supra at Part IV.A.1., and in part because the topic deserves a much more in-depth analysis than what this Article comprehends. Thus, a deeper examination of the issues raised by the damages element of this Article's proposed good faith claim is beyond the scope of this piece, but will be taken up in another.

181. See Houh, supra note 1.

182. See id. for an extensive discussion of good faith. Briefly, in that article, I address both the positive and normative questions of what good faith does and should require. At both a theoretical and doctrinal level, and through case analysis, that Article argues that modern courts in applying the two dominant models of good faith (sometimes simultaneously) have transformed good faith into an analytical framework for the evaluation of underlying breach of contract claims; that is, good faith has become detached from its equitable roots, functioning merely as a rhetorical proxy for breach of contract analyses. While such a transformation is not entirely a bad thing, in that it provides useful ways in which to think about the doctrine of material breach, that Article further argues that courts and commentators should not allow good faith to continue to be subsumed completely into the doctrines of material breach and constructive conditions. I also argue in that Article that the good faith doctrine is salvageable and that it should be resuscitated in a form closer to its equitable original. In this regard, I assert that the doctrine be given new life in two different ways: first, vis-à-vis its applicability to bad faith conduct in contract formation and negotiation, certainly not a new idea but one worth serious reconsideration; and, second, with respect to performance and termination, vis-à-vis its applicability in the context of discrimination based on race, gender, sexuality, and other categories of group identity, which is the subject of this Article. 
focuses on what constitutes "reasonable expectations" with respect to racial or gender subordination in the workplace. ${ }^{183}$

\section{a. What Can Employees Reasonably Expect?-Critical Race and Feminist Underpinnings}

In an attempt to move the "outsider"184 to the center of the good faith discrimination claim, its proposed elements are framed around the assumption that employees may reasonably expect not to be bound to perform in a certain way based on pre-existing racial and/or gender stereotypes, that is, employees may reasonably expect not to have to perform to a set of scripted identities in the workplace. In other words, any "scripted" expectation that an employer has of a particular employee related to his race (and/or gender) would be deemed unreasonable. This underlying premise incorporates important critical race and feminist insights. First, it rejects colorblindness and addresses "cultural imperialism" by legally acknowledging the existence of outsider stereotypes that are "attached in some way to their bodies, and which, thus, cannot be easily denied." 185 This underlying principle also recognizes that, left to fester, such scripted and pre-existing stereotypes that pervade the workplace and society at large-whether negative or positive ${ }^{186}$ - can negatively impact an outsider's work performance in concrete ways.

Second, framing reasonable expectations in this way for purposes of this claim shifts factual proof questions away from those relating to the alleged perpetrator's intent to discriminate, to those relating to how the existence of race and gender stereotypes manifest and burden those to whom such stereotypes attach. In more theoretical terms, the factual inquiries required of the good faith discrimination claim would enable a plaintiff to demonstrate the material manifestations of being designated as Other. ${ }^{187}$

183. See supra Part I.B.4. Of course, reasonable expectations in the context of good faith refers to many other kinds of expectations. For example, one can reasonably expect from her counter-party in contracting: full disclosure of material facts about the subject matter of the contract; substantial performance without known material deviation from contractual specifications; refraining from abuse of contractually reserved discretion; mitigating damages in event of breach; and fair and reasonable interpretation of contract provisions. Robert S. Summers, "Good Faith" in General Contract Law and the Sales Provisions of the Uniform Commercial Code, 54 VA. L. REv. 195, 203 (1968).

184. See supra Part I.A.

185. See id.; Young, supra note 11, at 59.

186. An example of a potentially harmful positive stereotype is that of the Asian Pacific American "model minority." See supra note 170.

187. See supra Part I.A.; Young, supra note 11, at 49-63. 


\section{b. Proving the Stereotype}

The first element of the proposed good faith discrimination claim requires a plaintiff to demonstrate the existence of factually-relevant racial and/or gender stereotype(s) in society generally and more specifically in the plaintiffemployee's former workplace, as well as the corresponding absence of a white male "image repertoire." 188 Proving this element would not be as onerous as it sounds. With respect to the general pervasiveness of stereotypes relating in particular to minority groups and/or women, research and scholarship on the causes and effects of stereotyping in the workplace and on productivity abound in the social sciences-particularly in management science and behavioral and cognitive psychology — as well as in areas dealing with more theoretical representational issues such as cultural studies. ${ }^{189}$ While proving that the existence of those stereotypes will be onerous to the first generation

188. The term "image repertoire" is borrowed from feminist film theorist and post-colonialist Trinh Minh-ha, who, in the specific context of Third World post-colonialism, uses it to refer to a finite set of representations that a dominant entity creates to Orientalize and dominate a subjugated entity as Other. Trinh writes:

This is the way the West carries the burden of the Other. Naming is part of the human rituals of incorporation, and the unnamed remains less human than the inhuman or sub-human. The threatening Othemess must, therefore, be transformed into figures that belong to a definite imagerepertoire. ... The perception of the outsider as the one who needs help has taken on the successive forms of the barbarian, the pagan, the infidel, the wild man, the "native," and the underdeveloped. Trinh T. Minh-ha, Woman Native Other: Writing Postcoloniality and Feminism 54 (1989). See also SAID, supra note 28 (defining Orientalism).

189. For examples of such scholarship in the management sciences, see Bengt Holmstrom \& Paul Milgrom, The Firm as an Incentive System, 84 AM. ECON. Rev. 972 (1994) (exploring how different levels of workplace incentives impact a worker's conduct); Herminia Ibarra, Making Partner: A Mentor's Guide to the Psychological Journey, 78 HARv. Bus. Rev. 147 (2000) (discussing conflict between employee's true sense of self and workplace culture at professional firms); Kevin Lang, A Language Theory of Discrimination, 101 Q.J. ECON. 363 (1986) (exploring whether outsiders who assimilate their conduct to that of dominant group fare better in the workplace). For examples in the areas of behavioral, cognitive, and social psychology, see Linda Hamilton Krieger, The Content of Our Categories: A Cognitive Bias Approach to Discrimination and Equal Employment Opportunity, 47 STAN. L. Rev. 1161 (1995) (arguing that many biased employment decisions result not from discriminatory intent or motivation, as current jurisprudence presumes, but from a variety of unintentional categorization-related judgment errors characterizing normal human cognitive functioning); Michael Selmi, Family Leave and the Gender Wage Gap, 78 N.C. L. REv. 707, 752 n.162 (2000) (citing studies that suggest that employers are likely to read ambiguous evidence as confirming prior preconceptions); Susan Sturm, Second Generation Employment Discrimination: A Structural Approach, 101 CoLum. L. REv. 458 (2001) (arguing that because "second generation" forms of bias result from patterns of interaction, informal norms, networking, mentoring, and evaluation, a more structural approach to regulating employment relationships is necessary to address more common forms of discrimination). For examples in cultural studies, see JUDITH BUTLER, BodiEs ThaT MATTER 136-39 (1993) (arguing that all people engage in a series of performances); Hall, supra note 123. 
of lawyers bringing the good faith discrimination claim, the benefits of this work would far outweigh its initial costs, as future generations of lawyers could rely on evidence introduced in successful "test" cases, needing only to update that evidence and research as necessary. Second, bringing such evidence to the attention of judges, defense lawyers, and juries would have great educational benefits that also might impact our more general sociocultural understandings of discrimination and racial and gender scripting. ${ }^{190}$ Third, in response to legitimate concerns over the overly theoretical direction of scholarly work on race and gender equality issues (and at the risk of sounding like a self-interested academic), the employment of such evidence would bring the work of practitioners and critical scholars closer together in their service to the common goal of a just and equal society. ${ }^{191}$

As to proving the existence of general relevant stereotypes in the more specific context of the plaintiff's former or current workplace, this Article suggests that myriad different kinds of evidence should be relevant and admissible to prove this element, since the employer's intent to discriminate is not at issue in the good faith discrimination claim. Examples of admissible and relevant evidence might include related workplace demographics, the sort

190. The litigation history of Grutter v. Bollinger, 539 U.S. 306 (2003), provides important precedent with respect to what kind of proof can (and, in some cases, should) be presented in cases involving discrimination. In the Grutter case, the University of Michigan Law School and the student intervenors presented evidence and testimony at trial of "a team of leading scholars [who served] as its experts in these cases to establish the basis for the University's argument that there is a compelling need for diversity in higher education." Expert Report: The Compelling Need for Diversity in Higher Education, 5 MicH. J. RACE \& L. 241 (1999) (publishing expert reports presented by the University of Michigan at trial in defense of its admissions policy; expert report authors included: Thomas Sugrue, Eric Foner, Albert Camarillo, Patricia Gurin, William Bowen, Claude Steele, Kent Syverud, and Robert B. Webster). Additionally, Professor Ian Ayres has collected an enormous amount of data that is quite persuasive in proving the continued existence of race and gender discrimination, which will continue to have a significant impact on future discrimination-related litigation. Ian Ayres, Pervasive Prejudice? Unconventional Evidence of RACE AND Gender Discrimination (2001); see also the website of The National Consumer Law Center for updates, available at http://www.nclc.org/ (last visited Nov. 29, 2004) (providing up dates on litigation stemming from the sort of empirical evidence gathered by Ayres and others).

191. Over a decade ago, the Honorable Harry T. Edwards, of the Court of Appeals for the District of Columbia, famously expressed his concerns over "the growing disjunction between legal education and the legal profession." Harry T. Edwards, The Growing Disjunction Between Legal Education and the Legal Profession, 91 Мich. L. ReV. 34 (1992). Judge Edwards criticized in particular what he then-viewed as the increasingly theoretical nature of legal scholarship in the fields, for example, of law and economics, law and literature, critical legal studies, critical race theory, and feminist legal theory. Id. at 34-35. He further questioned this scholarship's usefulness to practicing lawyers and to judges, and cautioned that the unmediated and continued emphasis on such theoretical scholarship in (elite) law schools would result in the desertion of a primary responsibility of law schools: to produce and train lawyers. Id. at 35 . 
of which might ordinarily be presented in a Title VII disparate impact claim, ${ }^{192}$ as well as anecdotal evidence. Significantly, because such anecdotal evidence would be presented not to show a hostile and pervasive work environment, as in the typical harassment case, but to demonstrate the existence of particular stereotypes in the workplace, evidence demonstrating the permissive use of racial or sexual epithets would create a strong presumption of performance-related scripting and stereotyping, since it would impose on the employee the unreasonable expectation to withstand such explicit and blatant manifestations of disrespect as part of her job.

In its defense against the establishment by the plaintiff of this element of the prima facie claim, a defendant-employer could introduce contradictory social science research on societal stereotyping. However, an employer most likely would concentrate its efforts on proving that the relevant stereotype did not exist or function discursively within its own workplace. Thus, for example, the employer could attempt to show that its workplace was meaningfully integrated, and that a "critical mass"-in the Grutter sense of that term ${ }^{193}$ — of women and/or people of color were employed there across departments. Or, the employer could demonstrate its attempts to combat these kinds of stereotypes through existing policies and/or programs.

\section{Identity}

c. Counter-Performing, Failing To Perform, and Over-Performing

Having alleged the existence of particular social stereotypes in the workplace, the plaintiff must next show how her "working identity" impacted

192. See Chamallas, supra note 58.

193. See Brief for Respondent at 40-43, Grutter v. Bollinger, 539 U.S. 306 (2003) (No. 02-241) (discussing why the University of Michigan Law School does not employ a "quota" in admitting a "critical mass" of minority students). In agreeing with the Law School, the Grutter Court stated:

The Law School does not premise its need for critical mass on "any belief that minority students always (or even consistently) express some characteristic minority viewpoint on any issue." [citation omitted]. To the contrary, diminishing the force of such stereotypes is both a crucial part of the Law School's mission, and one that it cannot accomplish with only token numbers of minority students. Just as growing up in a particular region or having particular professional experiences is likely to affect an individual's views, so too is one's own, unique experience of being a racial minority in a society, like our own, in which race unfortunately still matters ....

$\cdots$

... [T] he Law School engages in a highly individualized, holistic review of each applicant's file, giving serious consideration to all the ways an applicant might contribute to a diverse educational environment. The Law School affords this individualized consideration to applicants of all races. Grutter, 539 U.S. at 333, 337. 
her work performance. The specifics of her allegations would of course depend on the nature of the stereotype allegedly attached to her by her employer. Did she feel compelled to counter-perform her working identity because of negative (or positive) stereotypes that attached to her by, for example, speaking out against the imposed stereotypes or performing against script? If so, what kinds of risks did she incur in counter-performing? On the other hand, did she feel that she had to perform to a certain "positive" stereotype for fear that her failure to do so would result in negative action against her? If so, what kinds of conduct did she engage in and/or risks did she incur in response to that pressure? Because this element is so dependent upon the kinds of stereotypes attaching to the plaintiff, it will be discussed further in the context of the case analyses, infra.

\section{d. Adverse Employment Action and Its Impact}

In order to establish her prima facie good faith discrimination claim, a plaintiff would next have to allege that her employer took some negative or adverse employment action against her. Although the statutory civil rights claim also requires a showing of adverse employment action, this element for purposes of the proposed claim would employ a much broader definition of "adverse employment action" than Title VII jurisprudence does.

Under Title VII,"adverse employment action" is defined as a "materially adverse change in the terms, privileges, duration and conditions of employment," which includes " "discharge, refusal to hire, refusal to promote, demotion, reduction in pay, and reprimand," "194 as well as dissemination of negative employment references and issuing underserved negative performance reviews. ${ }^{195}$ Courts have further clarified that under Title VII, "not everything that makes an employee unhappy is an actionable adverse action" 196 and that a materially adverse action means more than "a mere inconvenience or an alteration of job responsibilities." 197 Thus, for example,

194. Treglia v. Town of Manlius, 313 F.3d 713, 720 (2d Cir. 2002) (quoting Morris v. Lindau, 196 F.3d 102, 110 (2d Cir. 1999)).

195. Brooks v. City of San Mateo, 229 F.3d 917, 928 (9th Cir. 2000). See also Burlington Indus., Inc. v. Ellerth, 524 U.S. 742, 761 (1998) (defining adverse employment action as a "tangible employment action [that] constitutes a significant change in employment status, such as hiring, firing, failing to promote, reassignment with significantly different responsibilities, or a decision causing a significant change in benefits").

196. Cullom v. Brown, 209 F.3d 1035, 1041 (7th Cir. 2000) (quoting Smart v. Ball State Univ., 89 F.3d 437, 441 (7th Cir. 1996)).

197. Id. (quoting Ribando v. United Airlines, Inc., 200 F.3d 507, 510 (7th Cir. 1999)). 
under Title VII, the suspension of a railroad employee without pay, followed thirty-seven days later by a reinstatement with back pay, constitutes adverse employment action, ${ }^{198}$ but taking certain action as to a female employee following her complaints of gender discrimination, including changing her duties, requiring her to report to different supervisor, not providing her with necessary training, tools, or software, and placing negative job memoranda placed in her personnel file, does not. ${ }^{199}$ Adverse action under the good faith claim would include the action taken against the female employee just described.

Moreover, while some courts have held that actions taken against plaintiffs by their employers that did not impact their formal status and salary cannot constitute adverse employment action under Title VII, the good faith claim would designate some forms of such conduct as negative action based on all of the factual allegations, including those relating to the remaining elements of the claim. For example, the transferring of an employee to a different location which lengthened her commute, giving her particularly

198. White v. Burlington N. \& Santa Fe Ry. Co., 364F.3d 789, 802 (6th Cir. 2004). See also Treglia v. Town of Manlius, 313 F.3d at 720 (finding that employer failing to promote employee who received highest score on examination for position and responding to employee's inquiry that although he had done a good job he would not receive a promotion "now or ever" and that employee should "get out of the business" was considered unlawful under definition of "adverse action"); Hashimoto v. Dalton, 118 F.3d 671, 674 (1st Cir. 1997) (finding that dissemination of adverse employment references can constitute adverse employment action if motivated by discriminatory intent); Florence v. Runyon, 990 F. Supp. 485, 496-98 (N.D. Tex. 1997) (finding that transfer of postal employee to less-desirable work hours and location but no change in pay, job title, or benefits following an employee's filing of discrimination charge could constitute retaliatory adverse employment action).

199. Cantrell v. Jay R. Smith Mfg. Co., 248 F. Supp. 2d 1126, 1137 (M.D. Ala. 2003) (finding that actions taken against female employee following her complaints of gender discrimination, including having her duties changed, being required to report to different supervisor, not being provided necessary training, tools, or software, and having negative job memoranda placed in her personnel file, did not constitute materially adverse employment actions, because they did not seriously and materially change terms, conditions, or privileges of work). See also Griffin v. Potter, 356 F.3d 824 (7th Cir. 2004) (transferring employee to different location which lengthened her commute combined with assigning her particularly difficult work assignments and refusing to approve her annual leave because of work backlog, does not constitute adverse employment action); Tran v. Trs. of State Colls. in Colo., 355 F.3d 1263, 1268-69 (10th Cir. 2004) (transferring of female corrections officer from male to female correction facility which did not impact duties, pay, title, or responsibilities did not constitute adverse employment action); Brooks v. City of San Mateo, 229 F.3d 917, 929 (9th Cir. 2000) (finding that allegedly retaliatory ostracism suffered at hands of a co-worker cannot constitute adverse employment action because employer's forcing employees to associate with each other might be unconstitutional); Cossette v. Minn. Power \& Light, 188 F.3d 964, 972 (8th Cir. 1999) (finding that unfavorable performance evaluation received six weeks following employee's filing charge with EEOC is not adverse action); Daniels v. BASF Corp., 270 F. Supp. 2d 847, 857 (S.D. Tex. 2003) (finding that negative employment action, even if inaccurate, is not adverse employment action under Title VII). 
difficult work assignments, including work arguably outside of her job description, and failure to approve her annual leave request because of work backlog resulting from the foregoing, might very well qualify as adverse action for purposes of the good faith claim. This would particularly be the case if the remaining elemental allegations, taken as a whole, would suggest that such negative action resulted in the reification of certain stereotypes or was taken because of those stereotypes (see infra regarding causation) ${ }^{200}$

The most important difference between Title VII standards of adverse action and the proposed good faith claim's standards is that while Title VII standards require, quite literally, a "materially" adverse change, evidenced by negative changes in salary, wage, status, and/or other similarly material conditions, the good faith claim's standards would allow and sometimes require a deeper inquiry into how and why the plaintiff believes that the actions taken against her were adverse. In other words, with respect to the example just given, the plaintiff asserting the good faith discrimination claim could have alleged that her work overload and transfer to a less convenient location constituted adverse employment action because, combined, these actions made here appear less competent than other employees who had not been given such difficult assignments and transferred to further locations. Further, if the plaintiff in this case had been, for example, a black woman, she could have argued that she was given these onerous assignments because she had "out-performed" a raced and gendered stereotype of general incompetence. On the other hand, if in this case many employees in the plaintiff's department had been given extra work and transferred to less convenient locations in the employer's comprehensive attempts to improve overall efficiency and output, the plaintiff would not have been able to show adverse impact resulting from the complained of action, absent other compelling facts.

\section{e. Causation}

Predictably, the element of causation, which links racial and gender scripting to adverse action and impact on the plaintiff, is the most difficult element to develop, particularly because conventional antidiscrimination discourse has taught us that the intent to discriminate is the linchpin of causation. How, then, should causation be theorized, given that one explicit

200. In Griffin, 356 F.3d at 828 , the court held that the actions described in this example did not constitute adverse employment action under Title VII. 
goal of this Article's proposed good faith discrimination claim is to deconstruct the dominant intent analysis?

In this regard, a lesson might be learned from corporate securities law's "fraud on the market" theory, which the Supreme Court adopted in Basic v. Levinson, ${ }^{201}$ a landmark securities fraud case. ${ }^{202}$ In somewhat over-simplified terms, the Court held that where a plaintiff-investor asserting a Rule $10 \mathrm{~b}-5^{203}$ violation could prove that the defendant had issued a materially misleading misstatement or misrepresentation about the stock and value of a company, the fraud on the market theory, which theorizes how information affects the market price of publicly-traded stock, ${ }^{204}$ could be used as a proxy for the reliance and causation elements of the $10 \mathrm{~b}-5$ claim. ${ }^{205}$ In other words, if a plaintiff-investor, in asserting his $10 \mathrm{~b}-5$ claim, can demonstrate the materiality ${ }^{206}$ of the alleged misrepresentation, the fraud on the market theory creates a presumption that the misrepresentation caused the investor to trade

201. Basic v. Levinson, 485 U.S. 224 (1988).

202. Antidiscrimination law and corporate and securities law may appear to be unlikely bedfellows, however, those who write on race and discrimination may have much to learn from corporate and securities jurisprudence. See, e.g., Anupam Chander, Minorities, Shareholder and Otherwise, 113 Yale L.J. 119, 119 (2003) (examining how corporate law and constitutional law have addressed the "problem" of minorities, and arguing that "[c]orporate law understands what constitutional law does not. Minority status matters to law.").

203. Together, section 10(b) of the Securities Exchange Act of 1934, 15 U.S.C. $\S 78 j$ (2000), and Rule 10b-5, 17 C.F.R. $\S 240.10 b-5$ (1993), constitute the primary anti-fraud weapon in federal securities law. Significantly, Rule 10b-5 not only permits the Securities Exchange Commission to bring enforcement actions, but it also provides a private cause of action for securities fraud. See Superintendent of Ins. v. Bankers Life \& Cas. Co., 404 U.S. 6, 13 n.9 (1976) (upholding lower courts' recognition of implied private actions for violations of Rule 10b-5). Briefly, in order to assert a Rule 10b-5 claim, a (private) plaintiff must show: "(1) fraud or deceit (2) by any person (3) in connection with (4) the purchase or sale (5) of any security.” Thomas Lee Hazen, The Law of Securities Regulation $\$ 12.4$ (4th ed. 2002). See also generally Donna M. Nagy et al., Securities Litigation and Enforcement: Cases and Materials (2003). Moreover, in proving fraud or deceit, a plaintiff must show materiality, reliance, causation, and damages. HAZEN, supra $\S 12.4$.

204. The Basic Court explained the fraud on the market theory accordingly:

The fraud on the market theory is based on the hypothesis that, in an open and developed securities market, the price of a company's stock is determined by the available material information regarding the company and its business.... Misleading statements will therefore defraud purchasers of stock even if the purchasers do not directly rely on the misstatements.... The causal connection between the defendants' fraud and the plaintiffs' purchase of stock in such a case is no less significant than in a case of direct reliance on misrepresentations.

Basic v. Levinson, 485 U.S. at 241-42 (quoting Peil v. Speiser, 806 F.2d 1154, 1160-61 (3d Cir. 1986)). 205. Id. at 241-50.

206. Materiality is itself subject to a "reasonable investor" standard. Id. at 232 (holding that the standard set forth in TSC Industries, Inc. v. Northway, Inc., 426 U.S. 438 (1976), whereby omitted fact is material if there is substantial likelihood that its disclosure would have been considered significant by reasonable investor, is applicable in section 10 (b) and Rule 10b-5 actions). 
on the stock because the investor presumptively relied on the material misrepresentation in so trading. ${ }^{207}$ Thus, if the defendant in a material misrepresentation case wishes to avoid liability, it must show how its misstatement did not affect the market price of the stock, since the fraud on the market theory allows for the presumption that misrepresentations $d o$ affect it. $^{208}$

While controversial, the fraud on the market theory is now wellestablished, and for good reason, especially if one accepts that our markets are imperfect. But, for purposes of this Article, one of the most significant aspects of the Court's opinion in Basic v. Levinson was its willingness to accept highly sophisticated and scholarly (and, as such, somewhat unsettled) economic theory in adopting the fraud on the market theory to presume reliance. Some have critiqued the Basic Court, claiming that its political commitment to strengthening anti-fraud statutes in the area of federal securities law was what truly motivated it to adopt the fraud on the market theory. ${ }^{209}$ However, regardless of what one thinks of the Court's political motivations in employing fraud on the market theory to create a rebuttable presumption of reliance based on materiality, surely it did better to consider and explicitly acknowledge the existing theory and scholarship, rather than to ignore the extensive research in the area and justify in a more tautological and dogmatic fashion the presumption of reliance.

With respect to the causation element of the good faith discrimination claim, I am suggesting that we do in some sense as the Basic Court did. Given the abundance of scholarship and research relating to race and gender stereotyping in many interdisciplinary fields, ${ }^{210}$ we can and should presume, where certain racial and gender stereotypes have attached and presented themselves in the workplace and the plaintiff has adjusted her performance according to those stereotypes, whether by counter-performing, overperforming, or under-performing, a correlation between those stereotypes in the workplace and the burdensome and unreasonable expectations imposed by the employer on the plaintiff as a result of her failure to perform and/or her

207. Id. at 241-49.

208. Id.

209. In fact, Justice White scathingly criticized the majority's employment of the fraud on the market theory in the Basic case. Id. at 250, 254 (White, J., dissenting) ("[W]hile the economists' theories which underpin the fraud-on-the-market presumption may have the appeal of mathematical exactitude and scientific certainty, they are - in the end — nothing more than theories which may or may not prove accurate upon further consideration. Even the most earnest advocates of economic analysis of the law recognize this.") (citation omitted).

210. See supra note 188. 
counter-performance of her working identity. Thus, the presumption that the plaintiff's counter-performance of her scripted working identity caused the alleged adverse employment action arises when the adverse action follows the counter-performance. The court may then find that there has been breach of good faith in that the employer has deprived the employee of her reasonable expectation of not having to perform to a stereotype; and, on the flipside, in that the employer has imposed unreasonable expectations on the plaintiff by requiring her to perform according to a scripted identity.

It is certainly possible that an employer might have taken adverse action against an employee simply because she was a bad employee, relatively or generally speaking. In the rhetoric of conventional antidiscrimination law, an employer might have taken action against an employee for a "legitimate business purpose." Under the good faith discrimination claim, the defendant could still defend itself in this way. But, the defendant would have to assert and prove its "legitimate business purpose" as an affirmative defense, rather than as part of a burden-shifting framework such as that one imposed by McDonnell-Douglas. Requiring the defendant to prove its legitimate business purpose as an affirmative defense would also eliminate the pretext analysis, which elimination is consistent with the dual goal of de-emphasizing and deconstructing discriminatory intent as the keystone of legally cognizable discrimination and making relevant the plaintiff's perspective on the circumstances of the alleged adverse action. ${ }^{211}$

\section{B. Critiques of Section 1981 Cases and Applications of the Good Faith Claim}

The absence of protections provided by federal and civil rights statutes against the type of performative identity discrimination at issue in this Article is exemplified in the case law. This subpart looks at four illustrative cases in which each of the plaintiffs brought — and lost—section 1981 claims, along with various other claims, for employment discrimination against their former employers. This subpart argues that each of these plaintiffs, however, did suffer some form of discrimination based on distinct forms of identity

211. Further, an employer could establish its legitimate business purpose defense by demonstrating that consistent expectations were imposed on all employees and that those expectations-in the form of the employer's various policies — had been communicated to allemployees, including the plaintiff; and that the plaintiff, having knowledge of those expectations and policies, failed to comply with them. Many might argue, rightly so, that this would pose a great threat to at-will employment. However, the protection of atwill employment is not something about which I am particularly concerned or that I wish to advocate. 
performance, and that they would have been much more likely to succeed in obtaining some relief if the proposed good faith discrimination claim had been available to them.

\section{Counter-Performing Identity: Shannon v. Ford Motor Co. ${ }^{212}$}

In Shannon v. Ford Motor Co., Fragena Shannon ("Shannon"), a black woman, sued Ford for its failure to promote her from the non-skilled position of "assembler" to the skilled-trades position of supervisor, asserting race and sex discrimination under section 1981, Title VII, and Minnesota's state antidiscrimination statute. ${ }^{213}$ Having successfully completed her skilled-trades training, Shannon first was placed on a wait-list for supervisory positions and then was moved to a wait-list for a skilled-trades apprenticeship position. ${ }^{214}$ After suffering an injury that caused a ten-month absence from work, Shannon returned to Ford, at which time Ford offered her a skilled-trades electrician apprenticeship that would require her to give up her spot on the supervisory wait-list. Not wanting to forego an opportunity in the skilled trades, Shannon took the electrician apprenticeship and was removed from the supervisory wait-list. $^{215}$ Subsequently, Shannon, one of very few women and/or African Americans in the program, suffered both racial and sexual harassment throughout her electrician apprenticeship and also alleged that she did not receive adequate training because of her race and sex. ${ }^{216}$

The district court granted summary judgment to Ford on Shannon's section 1981 and Title VII failure to promote claim, and the Eighth Circuit Court of Appeals affirmed. ${ }^{217}$ The court concluded that, assuming Shannon had made out a prima facie case, ${ }^{218}$ her claims would have failed because she

212. Shannon v. Ford Motor Co., 72 F.3d 678 (8th Cir. 1996).

213. Id. at 680-81.

214. Id.

215. Id. at 681 .

216. For example, on one occasion, one of her co-workers showed her a picture of a toilet and said to her, "[T] hat's you down there with all the other [...]." On another, she found a "sexually explicit "application for a date"" at her work station, which likewise had been placed there by a co-worker. Upon reporting these and other incidents of demeaning treatment to her supervisor, he "only laughed." Additionally, when Shannon complained to her supervisor that she was not receiving adequate training in the program, he responded, "[Y] ou are black and a woman, so you have two strikes against you. They don't want you [in the program] anyway." Id. at 681 n.2.

217. Id. at 685-86. Although Shannon was permitted to try her sexual harassment, sex discrimination, discriminatory retaliation, and other race discrimination claims, the jury found for Ford on all those claims. Id. at 681 n. 4 .

218. As a threshold matter, the court held that Shannon had not made out her prima facie case 
"produced no evidence that Ford's reason for not promoting her [was] a sham." 119 The court further noted that:

[Shannon's] "credibility has some weaknesses" and that Ford's "skepticism regarding [Ms. Shannon's] allegations that her poor work performance was caused by co-worker harassment and lack of training is supported by ... . [Ms. Shannon's] excessive absenteeism ... [her] argumentative and emotional behavior . . . [her] difficulty accepting directions and her attitude that her assignments were menial.",220

Significantly, the court conceded that while bias quite possibly infected Ford's apprenticeship program, this bias was not reasonably related to its failure to promote her. ${ }^{221}$

Under Title VII and section 1981, Shannon's claim failed at two critical points. At the outset, the court held that Ford's removal of Shannon from the supervisory wait-list did not constitute adverse employment action for purposes of the failure to promote claim. ${ }^{222}$ Second, even if it had, Shannon's claim failed - as so many do-at the pretext stage. This case also demonstrates how the pretext requirement, under which plaintiff must show that the employer's legitimate business purpose is false and a mere cover for intentional discrimination, not only precludes most plaintiffs from surviving summary judgment (since proving intent to discriminate is notoriously difficult), but also adds insult to this injury, for a plaintiff's failure to show pretext is used often to "prove" her "weak" credibility (read: pathological obsession with race). In part, based on its assessment of Shannon's lack of credibility, the court concluded that Shannon's allegations of harassment and lack of training in her electrician apprenticeship were immaterial to her failure to promote claim, since the former did not cause the latter. ${ }^{223}$

The court's rather shallow analysis in this case is both enabled and caused by conventional civil rights jurisprudence, which forces plaintiffs to assert one or a number of different types of intentional discrimination claims, such as, failure to promote, retaliatory discrimination, sexual or racial harassment, and, of course, discriminatory termination. Thus, even if the facts, taken together,

because her removal from the supervisory wait-list in exchange for the electrician apprenticeship did not constitute the sort of "rejection" required to assert both her section 1981 and Title VII claims. Id. at 682. 219. Id. at 683 .

220. Id. at 681 n.3 (quoting St. Paul Department of Human Rights' findings on Shannon's claim).

221. Id. at 685-86. Specifically, the court held that evidence of racial bias in the apprenticeship program did not satisfy the "reasonably related" standard of Title VII's administrative exhaustion requirement for discrimination claims. Id.

222. See id. at 685-86.

223. See id. at 683 . 
make a strong circumstantial case for racial or gender bias in the workplace, as the court acknowledged in Shannon, their parsing and decontextualization for purposes of establishing the different sub-species of claims often results in the failure of those distinct claims. Thus, plaintiffs' harms go unremedied.

Had the good faith discrimination claim been available to Shannon, she probably would have been able to obtain some measure of remedy, particularly because the claim requires a more holistic consideration of the facts and does not require plaintiffs to parse their claims and, hence, the facts giving rise to them. First, the facts, as reported in the published opinion evidence the existence of certain stereotypes of black women at Ford, specifically, in the skilled-trades environment. ${ }^{224}$ Assuming that evidence of general stereotypes could be proven through research and scholarship, the court noted certain stereotype evidence in footnotes. For example, on one occasion, one of Shannon's co-workers showed her a picture of a toilet and said to her, "[T] hat's you down there with all the other [.. .]."225 On another, she found a "sexually explicit 'application for a date"" at her work station, which likewise had been placed there by a co-worker. ${ }^{226}$ Upon reporting these and other incidents of demeaning treatment to her supervisor, he "only laughed."227 Additionally, when Shannon complained to her supervisor that she was not receiving adequate training in the program, he responded, "[Y]ou are black and a woman, so you have two strikes against you. They don't want you [in the program] anyway."228 Thus, Shannon-consistent with existing and especially malignant stereotypes of black people and black women-was scripted as incompetent ("down there with all the other [shit, or some form of excrement, we can assume]"), sexually available, and inferior and unwanted as both a woman and a person of color. ${ }^{229}$

224. See id.

225. Id. at 681 n.2.

226. $I d$.

227. $I d$.

228. See id. at 681 n.2.

229. For discussions of stereotypes of black women, see Patricia Hill Collins, Mammies, Matriarchs, and Other Controlling Images, in Black Feminist Thought: Knowledge, Consciousness, and the Politics of Empowerment 69 (2d ed. 2000) (quoting Trudier Harr is, From Mammies to Militants Domestics in Black American Literature 4 (1982) ("Called Matriarch, Emasculator and Hot Momma. Sometimes Sister, Pretty Baby, Auntie, Mammy and Girl. Called Unwed Mother, Welfare Recipient and Inner City Consumer. The Black American Woman has had to admit that while nobody knew the troubles she saw, everybody, his brother and his dog, felt qualified to explain her, even to herself.")); BELL HOOKS, Ain't I A Woman: Black Women And Feminism 65-86 (1981) (exploring stereotypes of black women as "beasts" and "sexual savages," aggressively matriarchal, Amazonian, and incompetent and un confident). 
Moreover, the court agreed with both Ford and the St. Paul Department of Human Rights ("Department"), which found that Shannon's lack of credibility in making her claims about the impact of the harassment and failure to train on her work performance was evidenced by her "excessive absenteeism ... . [her] argumentative and emotional behavior . . . [her] difficulty accepting directions and her attitude that her assignments were menial . . .." ${ }^{230}$ Neither the court nor the Department had considered, however, the obvious possibility that Shannon's absenteeism and other troubling conduct (to Ford, anyway) were themselves caused by her coworkers' harassment, her supervisor's condoning of this harassment, and Ford's failure to train her adequately. Instead, the court willingly used these facts to affirm stereotypes of the black woman worker as lazy ("excessive[ly]" absent[. . .]), aggressive and irrational ("argumentative and emotional"), and hostile to authority (in refusing to follow directions and complaining about menial work assignments). ${ }^{231}$

Thus, Ford expected her to act as the aggressive, hostile, lazy, emotional, and incompetent worker, imposing quite unreasonable expectations on her under the good faith claim. These expectations were made known to Shannon through both her co-workers and her supervisors. The good faith claim would next require Shannon to demonstrate how these unreasonable expectations impacted her work. Did she have to engage in extra work to counter-perform the stereotypes that Ford had attached to her? Or did the extra work manifest in Shannon's attempts to defy and defeat the scripted and unreasonable expectations imposed upon her, which in turn caused her to incur a certain amount of risk in speaking out against her "scripting," and ultimately resulted in her termination? The good faith claim would have required further inquiry designed to respond to these very important questions.

Moreover, the court's holding that Shannon's removal from the supervisory wait list in exchange for the skilled-trades electrician apprenticeship did not constitute adverse employment action is myopic. At the very least, the court should have inquired into whether such offers followed protocol at the Twin Cities plant, and into the nature of hierarchy at the plant. How were supervisors perceived there, as compared with other types of skilled-trades workers? What were the differences, both in terms of material compensation and "prestige," between the two positions that Shannon was forced to choose between? How did race and gender dynamics play out 
in the skills-trades, more generally? Again, the good faith claim would have required some inquiry into these questions, which in turn would bring the outsider experience to the center of the claim.

As to causation, further inquiry into the issues just discussed could very well lead to a conclusion that Shannon was offered a skilled-trades apprenticeship only if she forewent the opportunity to become a supervisor because black women were largely perceived at the Twin Cities plant (and more generally) as incompetent and not worthy of respect. Even based on the facts as reported, one senses that Shannon was set up for failure in the electrician apprenticeship, due in large part to the unreasonable expectations imposed upon her and the resulting difficulty she encountered in handling and responding to those expectations. She felt she was being scripted by coworkers and supervisors, she spoke up about it, her work performance likely was impacted as a result of it, and she was terminated. The good faith claim would have compelled a deeper inquiry into causation. While it might be true that Ford terminated Shannon because of poor work performance, what caused that poor work performance? While the treatment Shannon received at the hands of her co-workers and supervisors did not rise to the level of a "hostile environment" necessary to make out a sexual harassment claim under Title VII, her having to withstand and deal with that treatment certainly could have caused her work performance to suffer. Thus, under the good faith discrimination claim, a court could conclude that racial and gender scripting were the root causes for adverse employment action taken against Shannon. And, in defending itself against the claim by, for example, asserting the affirmative defense of the legitimate business purpose, Ford would have to take such scripting into account.

\section{Performing Against Identity: Manatt v. Bank of America ${ }^{232}$}

In Manatt v. Bank of America, a racial harassment and retaliatory discharge case, Li Li Manatt, a Chinese American, alleged violations of section 1981 based on harassing treatment she suffered during her two-and-ahalf years working in the trade finance department of a Portland, Oregon branch of the Bank of America ("Bank"). ${ }^{233}$ Specifically, Manatt endured racial epithets ("China Man" and "China Woman"), taunts relating to her 
"slanted" eye shape and, in particular, her accented spoken English. ${ }^{234}$ Manatt complained both to the Bank's human resources department as well as to her supervisor, Bill Gilmore, who, instead of being concerned for Manatt, admonished her for complaining formally to the human resources department. Gilmore also stated that the racial and ethnic taunting was "just joking" and "wasn't serious." 235 Following her complaints, Gilmore directed the trade finance employees to "be more sensitive about each other's feelings." 236 Although the taunting stopped after this, the Bank later transferred Manatt from the trade finance department to another division and, according to Manatt, started to reduce her job responsibilities, despite maintaining both her salary and title as a "trade finance specialist." Eventually, however, Manatt was given the title of "administrative assistant" to match her responsibilities on the job. ${ }^{237}$

The Ninth Circuit Court of Appeals upheld the district court's granting of summary judgment to the Bank on both of Manatt's claims. With respect to the racial harassment/hostile environment claim, the court held that the allegedly harassing conduct "was neither severe nor pervasive enough to alter the conditions of Manatt's employment." ${ }^{, 238}$ And, while the court stated that it was "certainly troubled" by incidents in which Manatt's colleagues disparaged her accent and pulled their eyes back to a slant, the court characterized this conduct together with the verbal taunting as "simple teasing" and "offhand comments," which under harassment law constitute non-actionable forms of discrimination. ${ }^{239}$

With respect to the retaliatory discharge claim, the court simply found no causal connection between Manatt's complaints about the harassment and her demotion within the Bank. After all, the court stated, Manatt herself had "admitted that the trade finance group [had] suffered from a reduction in workload" due to the Asian financial crisis, and pointed out that at some time after she had complained, Manatt had been selected to participate in a loanedexecutive program. ${ }^{240}$ Moreover, the court held that even accepting Manatt's allegations that her supervisor allowed her to be treated meanly by her co- 
workers following her complaints, "[m]ere ostracism in the workplace is not grounds for a retaliation claim." ${ }^{241}$

The Manatt case, typical of many harassment cases, is especially frustrating because it demonstrates the absurdity of judges announcing what constitutes harassment when they likely have never been subject to the type of harassment experienced by a plaintiff. ${ }^{242}$ Even a lay person might (reasonably) assume that racial taunting such as that experienced by Manatt is not to be tolerated in the workplace, however, because the taunting was not hostile and pervasive under existing harassment case law, Manatt's harms also went unremedied. Again, Manatt might have brought a successful good faith discrimination claim, where both her harassment and retaliation claims failed.

First, social stereotypes of Asians and Asian women in the workplace, even according to the reported facts, seemed to abound. Manatt was scripted as foreign ("China Man/Woman") based on her appearance (her "slanted" eyes) and her accent, which her co-workers ridiculed at some length. ${ }^{243}$ Asian Americans are commonly perceived in this way, regardless of whether they are fifth- or first-generation citizens. ${ }^{244}$ Also, in his disapproval of Manatt's reporting of the harassment to the human rights department and telling her that the taunting was "simple teasing," "just joking," and "wasn't serious," Gilmore (the supervisor) might have been imposing unreasonable expectations on her to endure such conduct precisely because she was acting against type, where that "type" requires Asians to be quiet and not rock the boat, and where it requires Asian American women to be especially passive and nonassertive. ${ }^{245}$ By refusing to allow herself to be subjected to what even the court called "offensive and inappropriate" 246 treatment, Manatt was

241. Id. at 803 .

242. The Honorable Richard C. Tallman, who wrote the majority opinion, is a 1978 graduate of the Northwestern University School of Law. The other two members of the panel deciding the case were the Honorable J. Clifford Wallace and the Honorable Donald P. Lay, graduates of the law schools at the University of California at Berkeley-Boalt Hall ('55) and University of Iowa College of Law ('51), respectively. Although the judges' racial backgrounds are unknown, they are presumably male based on their names. They are also likely white, based on the years of their graduation from law school and years on the federal bench.

243. Manatt, 339 F.3d at 795-96.

244. See Frank H. Wu, Yellow: Race in America Beyond Black and White 39-77, 79-129 (2002) (examining model minority and perpetual foreigner stereotypes of Asian Americans); Pat K. Chew, Asian Americans: The "Reticent" Minority and Their Paradoxes, 36 WM. \& MARY L. REv. 1 (1994) (exploring paradoxical stereotypes of Asian Americans, both in popular and legal discourses, and their damaging consequences); Cho, supra note 170; Saito, supra note 170.

245. See Chew, supra note 244, at 38; Cho, supra note 170.

246. Manatt, 339 F.3d at 798. 
performing against her script. Gilmore reminded her of this script and her non-compliance with it when he initially responded, essentially, that Manatt was overreacting and should have simply put up with the workplace "joking."247

While Gilmore did order Manatt's co-workers to be "more sensitive about each other's feelings," which finally resulted in the termination of the racial taunting, her subsequent demotion and transfer-both figurative and literal - constituted adverse employment action which followed her counterperformance, which Manatt claimed as retaliation on the Bank's part. ${ }^{248}$ The Bank offered its legitimate business purpose for her demotion/transfer and ultimate termination, arguing that it had demoted and terminated Manatt not because of her race and gender, but because the Bank's general reduction in workload required such transfers and because Manatt had not shown herself to be as competent an employee as others at her branch. ${ }^{249}$ Under the good faith discrimination claim, however, the Bank would have been required to show how it measured competence and how the reduction in workload had impacted the branch more specifically. For example, the court noted that "the Asian financial crisis" was one reason for the Bank's reduction in workload. ${ }^{250}$ Did the Asian financial crisis have a specific and significant impact on Manatt's work? Had she formerly been assigned to deal with Pacific Rim clients? Such inquiries could have been made under the good faith claim, and perhaps in the end, the Bank still would have prevailed if it had been able to respond to those questions sufficiently. But even in that case, better inquiries challenging discursive practices in the workplace could and would have been made.

3. Over-Performing Identity: Citroner v. Progressive Casualty Insurance Co. $^{251}$

The plaintiff in Citroner v. Progressive Casualty Insurance Co., George Citroner, was a Latino ${ }^{252}$ male who was hired by Progressive as a claims adjuster/representative. Shortly after beginning his employment, Citroner was

247. Id. at 796 .

248. $I d$.

249. Id. at 801 .

250. Id.

251. Citroner v. Progressive Cas. Ins. Co., 208 F. Supp. $2 d 328$ (E.D.N.Y. 2002).

252. Demonstrating a rather sophisticated understanding of multiracial identity categories, Citroner also identifies himself, in varying parts, as Argentinean, Puerto Rican, white, black, and Asian. He also identifies himself as being "tan" in skin color. Id. at 332. 
pulled aside by his supervisor John Noto, who, upon hearing Citroner speaking Spanish with a client, instructed him to "act more "white" and to "“lose that cocky Spanish attitude." "253 According to Citroner, Noto also gave more work to Citroner than to other similarly-situated employees in an attempt to drive him out of the job and often yelled at him, calling him "Speedy Gonzalez" in front of his many co-workers. ${ }^{254}$ At various times during his employment, Noto also directed Citroner to remove an Argentinean flag from and placed a Speedy Gonzalez doll at his workstation, mocked the way he spoke Spanish, berated him as stupid, incompetent, an idiot, and a monkey, and made negative comments about Latinos generally. ${ }^{255}$ After complaining about this conduct and receiving little or no response, Citroner indicated a willingness to resign from Progressive. Shortly thereafter, Progressive terminated him. Citroner subsequently sued Progressive, alleging claims of hostile work environment harassment and discriminatory termination/constructive discharge, pursuant to both Title VII and section $1981 .^{256}$

The court granted summary judgment to Progressive on both the harassment and discriminatory termination claims. Here, as in Manatt, the court held that the conduct Citroner complained of did not rise to the level of extraordinary severity required by harassment law. ${ }^{257}$ Moreover, with respect to the discriminatory discharge claim, the court held that assuming Citroner had made out his prima facie case under the McDonnell-Douglas burdenshifting framework, he had failed to rebut as mere pretext Progressive's articulated legitimate reason for his termination, which involved a disputed altercation between Citroner and another Progressive claims adjuster/representative. ${ }^{258}$

The stereotypes at work in this case are obvious and require little discussion. More interesting is that this case involves the perceived "overperformance" of identity. That is, Citroner, knowing that his supervisor held some contempt for Latinos generally, continued to speak Spanish to Spanishspeaking customers and continued to display an Argentinean flag at his work station, despite Noto's disapproval of both. In other words, in refusing to "tone down" his racial and ethnic background and in refusing to "act more

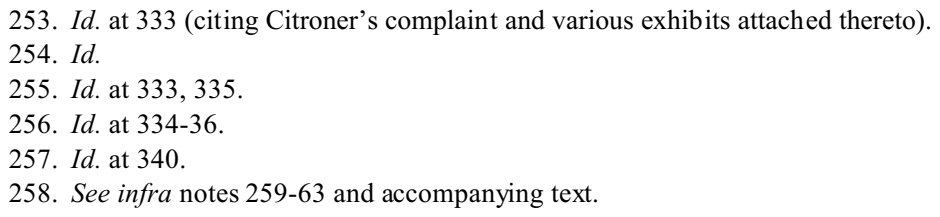


white"-expectations which never should have been placed upon him in the first place - Citroner incurred risks, which ultimately materialized in his work performance and ultimate termination, by not assimilating in the way that Noto demanded.

The causation element again requires further explanation and inquiry, and Progressive's legitimate business purpose warrants some detailed discussion in that regard. Progressive claimed that Citroner was terminated because of an altercation between him and one of his co-workers, Tina Albanese, which also led to complaints that Citroner was threatening to female workers. ${ }^{259}$ Apparently, it was known throughout the workplace that Citroner and Noto did not get along. One night as Citroner was leaving work with co-worker Dominick DeCicco, he approached Albanese, who was in her car, and purportedly stated to her that he had "heard that you hope that I get fired." 260 Albanese responded that although she did not like Citroner, they could work together. According to Albanese, Citroner then "exploded" at her, screaming and cursing at her so menacingly that she feared he would strike her. ${ }^{261}$ Citroner, on the other hand, testified that Albanese had approached him as they were leaving work and that he stated that he had heard that she hoped he would be fired. Citroner alleged that both he and Albanese had yelled at each other, but he denied cursing at her. ${ }^{262}$ Other witnesses' accounts of the altercation matched Albanese's account, while DeCicco's account offered yet another version of the altercation, which involved only Albanese's cursing and screaming at a calm and reserved Citroner. ${ }^{263}$

Albanese's version of the altercation is especially troubling and if credibly supported, Progressive certainly could have prevailed in asserting legitimate business purpose as an alternative defense under the good faith discrimination claim. As in the Manatt case, however, it seems a deeper inquiry into causation and stereotyping, both about the racial harassment and the altercation between Citroner and Albanese, would have been helpful on many levels, and which could occur during the defendant's presentation of its affirmative defense. While the scripting issues as they relate to the alleged harassment are fairly obvious, do they likewise exist in different form with

259. Citroner, 208 F. Supp. $2 d$ at 333.

260. Id. at 334 .

261. Id. at 334-35. Albanese specifically alleged that Citroner called her a "fucking whore bitch" and a "cunt bitch." Id.

262. Id. at 335 .

263. Id. at 338-39. 
respect to the altercation? In Rashomon ${ }^{264}$ fashion, does the "true" story of what happened between Citroner and Albanese lie somewhere between their versions of the altercation? To what extent are their versions of the story informed by racial and gender scripting of Latino males as predatory ${ }^{265}$ and of assertive women as "bitches"? ${ }^{266}$ From both a feminist and critical race perspective, the Citroner case is deeply distressing, for it implicates not only raw racism but the much more complicated and intersectional issues of raced patriarchy and misogyny and gendered and sexualized racism. In the end, here, as in Manatt, Citroner might have failed on his good faith claim if Albanese's version of the altercation had proven to be more credible. However, given its potentially raced and gendered nature, the altercation itself deserves a much deeper level of inquiry than conventional civil rights law allows, but which the good faith causation element would require.

264. Rashomon (R.K.O. Radio Pictures 1950). This classic film, directed by Akira Kurosawa, is a brilliant interrogation of subjectivity and the ultimate instability of the facts that constitute "truth." The film tells the "story," set in a forest in feudal Japan, of a bandit's rape of the wife of a samurai and the subsequent murder of the samurai by the bandit. The story of the crime unfolds before the "court"-or the camera and, thus, the film viewer-in a series of flashbacks; that is, the crime is recounted in turn and in testimonial fashion by each of the three main players - the bandit, the dead samurai (through a medium), and the samurai's wife (i.e., the victim) - and then finally, by a woodcutter who, hiding among the trees, witnessed the rape and murder as an "uninvolved" but deeply impacted observer/witness. Each of the three "players" conveys a story that is similar in some details, but profoundly different in others, as each narrator remembers and retells the story in a manner that makes him or her least culpable and most innocent. These divergent narratives are not offered, however, for the purpose of making the viewer predict whose story is the true one, but rather to compel the viewer to contemplate the very notion of truth. Is the "true" story of the rape and murder really knowable in any objective sense? Or do the subjectivities of each of the narrators/players make the truth unknowable? Although the woodcutter's version is offered at the end of the film as perh aps the "real" version of the story, the film viewer is left to wonder whether even his version of the story is true, for we know little of what informs his interpretation of the heinous events.

265. See David G. Gutierrez, Walls and Mirrors: Mexican Americans, Mexican Immigrants, AND the Politics of Ethnicity (1995); J. Jorge Klor de Alva, The Invention of Ethnic Origins and the Negotiation of Latino Identity, in Challenging Fronteras: Structuring Latina AND Latino Lives in the U.S.: An ANTHology of Readings 55 (Mary Romero et al. eds., 1997) (examining " $[\mathrm{t}] \mathrm{o}$ what extent ... Chicano or Puerto Rican 'latino' identities are a result of the subordinate status of the community ... and to what extent ... [they are] evidence of the vitality of cultural negotiation in a complex multiethnic society"); see generally Otto Santa Ana, Brown Tide Rising: Metaphors of Latinos in CONTEMPorary American Public Discourse 65-103 (2002) (exploring usage of stereotypes of Latinos as aggressively invasive and animalistic during the campaign to place Proposition 187 on the California ballot).

266. See, e.g., Guerrilla Girls, Bitches, Bimbos, and Ballbreakers: The Guerrilla Girls' ILlustrated Guide to Female SteREOTYPES 25-26 (2003) (exploring history of stereotypes of feminist women). 
4. The Case of the White Plaintiff: Bainbridge v. Loffredo Gardens, Inc. ${ }^{267}$

Bainbridge v. Loffredo Gardens is unlike other cases discussed in this subpart in that it involves a white male plaintiff who brought his Title VII and section 1981 claims against Loffredo not for, as one might guess, reverse discrimination, but for harassment based on derogatory comments made about Asians in particular, and other minorities more generally. Loffredo Gardens, a fresh produce company, hired Thomas Bainbridge as its warehouse manager. Almost from the start of his employment, Bainbridge heard the Loffredos (Mike, Jim, and Larry), owners and upper managers of the company, collectively and frequently refer to Asians as "Jap," "nip," and "gook" and to other minorities as "spic," "wetback," "monkey," and "nigger."268 The Loffredos allegedly demonstrated an especial hostility toward "Jap" produce companies, as Mike Loffredo perceived that Japanese corporations were driving them out of business. ${ }^{269}$ The anti-Japanese sentiment at the workplace made Bainbridge particularly uncomfortable, as he was married to a Japanese American woman. According to Bainbridge, when he reminded the Loffredos about his wife's ethnicity, they stepped up the derogatory remarks in order to "aggravate" him. ${ }^{270}$

Bainbridge complained to an immediate supervisor about the harassment, who indicated he would take care of the problem. But when Bainbridge left for vacation shortly after registering his complaint, three supervisors, including the one to which he had spoken about the harassment, complained to the Loffredos that Bainbridge behaved abusively and threatened to leave if the Loffredos did not terminate Bainbridge. ${ }^{271}$ Thus, upon his return from vacation, Loffredo terminated Bainbridge. Bainbridge subsequently filed suit under Title VII, section 1981, and Iowa's state civil rights statute claiming that as a result of his association with a Japanese American, he had suffered from a hostile work environment because of the derogatory comments made about Asians and other minorities by the Loffredos and that he had been terminated in retaliation for his complaints about the harassing conduct. ${ }^{272}$

267. Bainbridge v. Loffredo Gardens, Inc., No. 4:02-CV-40192, 2003 WL 21911063 (S.D. Iowa July 31,2003 ).

268. Id. at *1.

269. $I d$.

270. $I d$.

271. Id. at $* 2$.

272. $I d$. 
The court granted the Loffredos' motion for summary judgment, which had been filed on procedural and substantive grounds, and held on the merits that not only had Bainbridge failed to allege a prima facie case of discrimination, but even if he had, he had failed to demonstrate that Loffredo's termination of him for his purportedly abusive behavior was a pretext for intentional discrimination. ${ }^{273}$ Not unexpectedly, given the way the burden-shifting framework operates, Bainbridge's retaliation claim failed specifically because of this failure to show pretext. The court's hostile environment analysis is significantly more interesting, however.

The court noted that while a white person is not protected directly under section 1981, he or she may assert a section 1981 harassment claim based on his or her association with a protected minority. ${ }^{274}$ However, in order for the harassment to be actionable under section 1981, it must be "specifically directed at the person's association with a non-white."275 And although one of Bainbridge's former co-workers testified in a sworn declaration that he had heard other Loffredo employees refer to Bainbridge's wife as his "chinky girlfriend" or "gook girlfriend," those comments were irrelevant because Bainbridge himself had not been aware of them. ${ }^{276}$ Moreover, the court stated that in order for Bainbridge to make his prima facie harassment claim, he had to show that the racially derogatory comments he had been aware of were truly unwelcome by him. The court reasoned that because Bainbridge had "not indicated that he objected to hearing derogatory remarks about Blacks or Hispanics, or that he in any way indicated that racial slurs about Blacks and Hispanics were unwelcome," his environment had not been sufficiently hostile or abusive. ${ }^{277}$

In this case, Bainbridge, like Andrew in the hypothetical in Part I.B.4 of this Article, exemplifies a white male who typically would not be subjected to a particular image repertoire in the workplace, but for the fact of his chosen outsider-alignment. The difference between Bainbridge and the hypothetical Andrew is the nature of the alignment, which is personal for Bainbridge and political and professional (and perhaps personal, as well) for Andrew.

With respect to the good faith elements of existing workplace stereotypes and performing against identity, the Loffredo opinion is especially troubling for several reasons. First, the court presumes that white employees do not 
experience legally cognizable harassment because of an employer's regular use in the workplace of extremely derogatory racial epithets such as "spic," "wetback," "monkey," "nigger," Jap," "nip," “chink," and "gook," perhaps because all Whites are presumed to be "in on the joke," which in turn implicates the normalization of white supremacist values and beliefs. Second, even when some of those terms were used to refer directly to Bainbridge's association with an "outsider"-his Japanese American wife-the court designates those comments as immaterial because although Bainbridge's coworkers had been aware of such comments, Bainbridge had not been. Here, the court wrongly assumes that comments made about Bainbridge's interracial relationship not only would not be offensive to his white co-workers, but would have no impact on their perceptions of Bainbridge as one not worthy of respect because of his marriage to a "gook." And finally, the court rubs salt in Bainbridge's wounds by not only dismissing his claims based on his not being aware of comments referring to his "chinky girlfriend," but also chastising him for not being sufficiently offended by the Loffredo's derogatory comments about non-Asian minorities! Notably, though, even if Bainbridge had voiced more concern over such comments, they would have been irrelevant to the court since in order for them to be actionable under section 1981, they must be "specifically directed at the person's association with a non-white."278

The good faith discrimination claim would have enabled Bainbridge not only to obtain some remedy for harm he suffered as an outsider-aligned white male but also to begin to deconstruct the sociocultural paradigm of White versus Other, of the purportedly unraced and the raced.

\section{CONCLUSION}

This Article has employed "critical race realism" to theorize a good faith discrimination claim. In doing so, it has attempted two interventions, one doctrinal and one theoretical. Doctrinally, the good faith discrimination claim explicitly traverses the boundary between public and private law by using the contractual doctrine of the implied obligation of good faith to effect a public law norm of equality. Theoretically, the good faith discrimination claim attempts to take account of and actualize Iris Marion Young's "five faces of oppression" by operationalizing Devon Carbado and Mitu Gulati's theory of "working identity." Moreover, the good faith discrimination claim attempts 
to drive theory into praxis by shifting its analytical inquiry away from intentionality and the "perpetrator perspective"-so deeply embedded in conventional civil rights law - and directly toward the conditions and agents, both material and ideological, of group-based subordination. It is important to point out that this Article does not argue that racial and gender identity and difference, specifically as those identities are lived in the workplace, should be deconstructed to the point of non-existence. Rather, the good faith discrimination claim means to address, contextually and specifically, the material burdens and risks imposed on workplace-outsiders by their ideological "image repertoires." In this way, the claim hopes to produce not less, but more, discussion about race and gender in the workplace, discussion that captures the profound complexity of what it means to live and work in a diverse society.

It is my hope, also, that this Article will help bring critical scholars, legal realists, and contracts scholars together, so that we might rekindle the controversy over what constitutes the public and private law in American jurisprudence, and so that we might continue to interrogate how our constructions and/or deconstructions of the public-private dichotomy implicate and affect our common goal: the elimination of the material and ideological conditions and causes of inequality. 